\title{
The influence of surface soil physicochemistry on the edaphic bacterial communities in contrasting terrain types of the Central Namib Desert
}

\author{
S. GOMBEER, ${ }^{1}$ J.-B. RAMOND, ${ }^{1}$ F. D. ECKARDT ${ }^{2}$ M. SEELY ${ }^{3,4}$ AND D. A. COWAN ${ }^{1}$ \\ ${ }^{1}$ Centre for Microbial Ecology and Genomics (CMEG), Genomics Research Institute, University of Pretoria, Pretoria, South \\ Africa \\ ${ }^{2}$ Environmental and Geographical Science, Department of Geography, University of Cape Town, Cape Town, South Africa \\ ${ }^{3}$ Gobabeb Research and Training Centre, Walvis Bay, Namibia \\ ${ }^{4}$ School of Animal, Plant and Environmental Sciences (AP\&ES), University of the Witwatersrand, Johannesburg, South Africa
}

\begin{abstract}
Notwithstanding, the severe environmental conditions, deserts harbour a high diversity of adapted micro-organisms. In such oligotrophic environments, soil physicochemical characteristics play an important role in shaping indigenous microbial communities. This study investigates the edaphic bacterial communities of three contrasting desert terrain types (gravel plains, sand dunes and ephemeral rivers) with different surface geologies in the Central Namib Desert. For each site, we evaluated surface soil physicochemistries and used explorative T-RFLP methodology to get an indication of bacterial community diversities. While grain size was an important parameter in separating the three terrain types physicochemically and specific surface soil types could be distinguished, the desert edaphic bacterial communities displayed a high level of local spatial heterogeneity. Ten variables contributed significantly $(P<0.05)$ to the variance in the T-RFLP data sets: fine silt, medium and fine sand content, $\mathrm{pH}, \mathrm{S}, \mathrm{Na}$, $\mathrm{Zn}, \mathrm{Al}, \mathrm{V}$ and Fe concentrations, and $40 \%$ of the total variance could be explained by these constraining variables. The results suggest that local physicochemical conditions play a significant role in shaping the bacterial structures in the Central Namib Desert and stress the importance of recording a wide variety of environmental descriptors to comprehensively assess the role of edaphic parameters in shaping microbial communities.
\end{abstract}

\section{INTRODUCTION}

Desert ecosystems, which form the largest terrestrial biome covering circa $35 \%$ of the Earth's land surface, are defined by a precipitation to potential evaporation ratio lower than 1 (Pointing \& Belnap, 2012). They are characterised by an elevated desiccation potential, high UV radiation and extremely fluctuating daily and seasonally temperatures (Pointing \& Belnap, 2012). In addition, deserts are typically low-energy ecosystems with limited nutrient availability (Pointing \& Belnap, 2012). Notwithstanding, these severe conditions, both hot and cold deserts harbour a high diversity of micro-organisms (e.g. Aislabie et al.,
2008; Direito et al., 2011; Andrew et al., 2012; Lee et al., 2012; Makhalanyane et al., 2013). It has been shown that in oligotrophic environments such as deserts, where food webs are generally simple, soil physicochemical characteristics such as water availability (Drees et al., 2006; Clark et al., 2009; Wichern \& Joergensen, 2009), pH (Andrew et al., 2012; An et al., 2013; Geyer et al., 2013), carbon content (Wichern \& Joergensen, 2009; Andrew et al., 2012; Geyer et al., 2013), nitrate concentration (BenDavid et al., 2011), salt content and conductivity (Andrew et al., 2012; Lee et al., 2012; Geyer et al., 2013) and particle structure (Wichern \& Joergensen, 2009; Ehrenfreund et al., 2011; Andrew et al., 2012) play a significant role in 
shaping indigenous microbial communities (Lee et al., 2012)

In addition, micro-organisms contribute to the weathering of rock formations in desert ecosystems (Chen et al., 2009; Borin et al., 2010; Kutovaya et al., 2012) and microbial community structures are influenced by the substrate mineral composition (Gommeaux et al., 2010; Pietrasiak et al., 2011; Steven et al., 2013). An analysis of the influence of soil parental material on the distribution of microbial soil crusts in the Mojave and Colorado Deserts (Pietrasiak et al., 2011) demonstrated that the proximity to granite bedrock and its associated 'grusy' granite soils were key determinants in crust distribution, indicating the importance of geology in shaping desert microbial soil crusts. Biological soil crusts of the Colorado Plateau also exhibited differences in crust community composition between various soil types, where gypsum soil microbial assemblages were the most divergent (Garcia-Pichel et al., 2001; Bowker \& Belnap, 2008; Steven et al., 2013).

The Namib Desert, one of the world's oldest deserts with an estimated age of 80 million years (Prestel et al., 2008), covers much of the western coast of Namibia (Southgate et al., 1996). It can roughly be divided into two very different latitudinal zones: the northern gravel deserts (dominated by gypsum, calcretes and with extensive quartz pebble desert pavements; Eckardt et al., 2013a), and the southern 'sand sea' (a recently declared UNESCO World Heritage Site), a region of parallel dune and interdune structures running in a north-south orientation (Southgate et al., 1996). The two zones, separated by the Kuiseb River, differ hugely in geological composition, microclimate and macrobiology (Eckardt et al., $2013 a, b)$.

In this study, the edaphic bacterial communities of the three contrasting desert terrain types, described above (i.e. gravel plains, sand dunes and ephemeral rivers), were investigated. The study was conducted in the hyperarid Central Namib Desert. The terrain types consisted of different surface geologies and we evaluated the effect of the underlying lithologies (e.g. schist, granite, sandstone) as well as younger silts, sands, conglomerates, gravels and salts on surface soil physicochemistry and bacterial community diversities. Soils from all three terrains were collected and characterised physicochemically, by recording 30 environmental parameters, and biologically, by exploring the bacterial community structure using T-RFLP fingerprinting. This holistic approach was applied to investigate (i) whether desert soil terrain types can be distinguished physicochemically and/or biologically, (ii) whether the subsurface geological formation defines the physicochemical characteristics of the desert surface soils, (iii) whether T-RFLP fingerprints of edaphic bacterial communities can be linked to specific terrains and/or underlying geologies and (iv) whether it is possible to identify specific soil physicochemical characteristics as significant drivers of desert edaphic bacterial assemblages.

\section{MATERIAL AND METHODS}

\section{Study area, site selection and sample collection}

The sampling was conducted in the vicinity of the Gobabeb Research and Training Centre (GRTC) in the Central Namib Desert (Fig. 1). We sampled different surface materials including schist, granites, calcified cover, calcified conglomerates, sandstone, dune sand, silts and gravels originating from three contrasting desert terrain types, that is an ephemeral river, the gravel plains and the sand dunes, which harbour a range of established surface geologies. (Table 1) (Eckardt et al., 2013a).

Apart from the riverine Gobabeb Gravels, surface materials from replicate and geographically distinct sites, that is set at least a few hundred metres apart, were sampled to test intraterrain-type and intrageological-unit variability. This resulted in the sampling of desert soils from a total of 22 sites (Fig. 1; geological characterisations, Table 1; site coordinates, Table S1). At each sampling site, four true replicate surface $(0-5 \mathrm{~cm})$ soil samples were collected aseptically. Each true replicate sample corresponded to a mixture of 5 pseudo-replicates taken within a $1 \mathrm{~m}^{2}$ quadrat and collected at the vertices of a $50-\mathrm{m}$ perpendicular cross (Fig. 1). For the Gobabeb Gravels (GB), the 4 replicate samples were taken on selected terraces and at the Homeb Silt sites (HM) surface soil was scraped off the silt castles. The samples were collected in sterile Whirl-Pak ${ }^{\circledR}$ sampling bags (Nasco, Wisconsin, USA) and stored at room temperature for $48 \mathrm{~h}$ prior to their arrival at the Centre for Microbial Ecology and Genomics (University of Pretoria, South Africa). Aliquots were then stored at $-20{ }^{\circ} \mathrm{C}$ for subsequent molecular analyses and the residual soil at $4{ }^{\circ} \mathrm{C}$ for physicochemical analyses.

\section{Environmental descriptors}

Each soil sample was characterised by 30 environmental descriptors (Table S1). The particle size analysis (PSA) was performed by means of laser diffraction on a Malvern Mastersizer 2000 attached to a Hydro 2000G wet sample dispersion unit. We measured surface weighed mean (SWM) and the accumulated percentages in different size categories described in ISO 14688-1 (clay, fine silt, medium silt, coarse silt, fine sand, medium sand and coarse sand). The moisture content was evaluated as the percentage weight loss after drying $2 \mathrm{~g}$ of soil at $100{ }^{\circ} \mathrm{C}$ for $12 \mathrm{~h}$. The $\mathrm{pH}$ was recorded with a $\mathrm{pH}$ metre (Crison basic 20, Barcelona, Spain) by dissolving $10 \mathrm{~g}$ of soil in deionised water at a 1:2.5 soil/water ratio (Eckert \& Sims, 1995). 


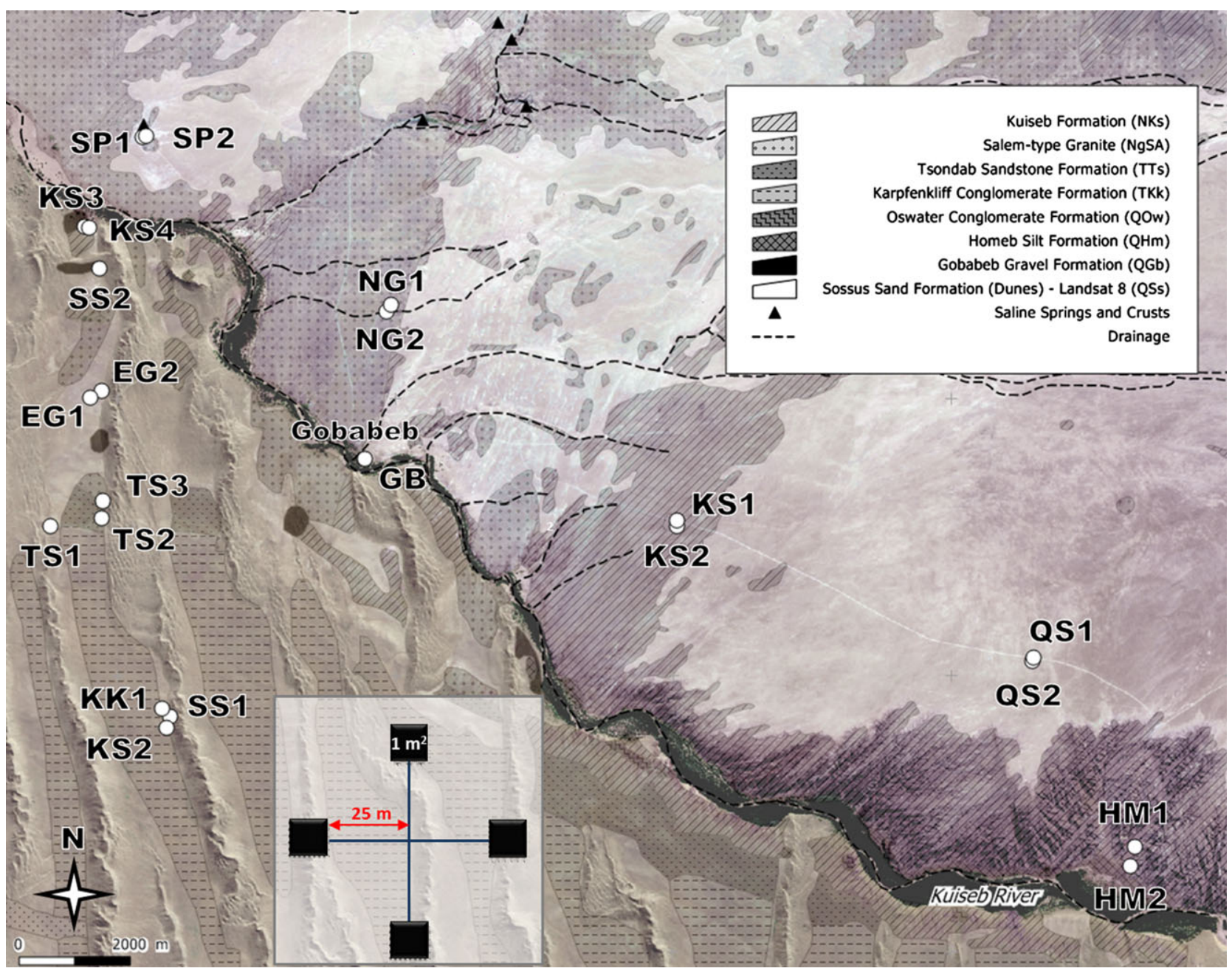

Fig. 1 Map of the Central Namib Desert in the vicinity of the Gobabeb Research and Training Centre (GRTC) displaying the different geologies, the Kuiseb River and the locations of the sampling sites. The site codes and geological characterisation are described in Table 1 and the site coordinates in Table S1. The inset schematises the sampling strategy employed at each site; $\mathbf{\square}: 1 \mathrm{~m}^{2}$ replicate sampling site.

Total nitrogen present as ammonium $\left(\mathrm{NH}_{4}^{+}-\mathrm{N}\right)$ and as nitrate $\left(\mathrm{NO}_{3}^{-} \mathrm{NO}_{3}^{-} \mathrm{N}\right)$ was extracted with a potassium chloride solution (1M) and determined by steam distillation and subsequent titration as described by Keeney \& Nelson (1982). Prior to all other analyses, the soils were sieved $(2 \mathrm{~mm})$ and dried overnight at $37^{\circ} \mathrm{C}$. Total carbon (\%) was measured by oxidising the organic material with potassium dichromite and sulphuric acid, and titrating the excess dichromite (Walkley, 1935; Nelson \& Sommers, 1982). Extractable phosphorus was determined with the Bray-1 method (Bray \& Kurtz, 1945). The cation exchange capacity (CEC) was measured using an ammonium acetate solution as extractant for the exchangeable plus water-soluble cations. The initial ammonium acetate extract (1M) was analysed using an ICP-OES (Spectro Genesis, Spectro Analytical Instruments GmbH, Germany) to measure $\mathrm{Na}, \mathrm{K}, \mathrm{Mg}$, Ca and $\mathrm{S}$ concentrations. Further extractions with ammonium acetate $(0.1 \mathrm{M})$ and potassium chloride $(1 \mathrm{M})$ were steam distilled to separate the ammonia which is taken as an equal of the CEC of the soil (Rhoades, 1982). Trace elements and heavy metals (Al, Cd, Cr, $\mathrm{Cu}, \mathrm{Fe}, \mathrm{Mn}, \mathrm{Ni}, \mathrm{Zn}, \mathrm{V}$ and $\mathrm{Co}$ ) were extracted from $10 \mathrm{~g}$ of soil using an EDTA buffer and measured with an ICPOES, after filtering through a $0.45-\mu \mathrm{m}$ Millipore filter (EMD Millipore Corporation, Billerica, MA, USA).

\section{DNA extraction, PCR protocols and terminal restriction fragment length polymorphism (T-RFLP) analyses}

As our aim was to compare bacterial communities from desert soils with different physicochemestries, we extracted total soil DNA using a single method (Lombard et al., 2011): the PowerSoil ${ }^{\circledR}$ DNA Isolation kit (MO BIO Laboratories, Carlsbad, CA, USA), following the manufacturer's 
Table 1 Geological characterisation of the Namib Desert surface soils sampled with their survey codes used on the map in Fig. 1 (Eckardt et al., $2013 a$ )

\begin{tabular}{|c|c|c|c|c|c|}
\hline Sampling sites & Unit name & Lithology & Geologic period & Age & Survey codes \\
\hline \multicolumn{6}{|l|}{ Gravel Plains } \\
\hline KS 1 and 2 & Kuiseb & Schist & Precambrian & $\pm 880-460 \mathrm{Ma}$ & NKs \\
\hline NG 1 and 2 & Salem & Granite & Cambrian & $\pm 575-523 \mathrm{Ma}$ & $\mathrm{NgSa}$ \\
\hline QS 1 and 2 & Surficial Cover & Surficial Cover & Quaternary & Modern & Qs \\
\hline SP 1 and 2 & Saline Spring & Salt Crust & Quaternary & Modern & No Code ( $\Delta$ on map) \\
\hline \multicolumn{6}{|l|}{ Dunes } \\
\hline TS 1,2 and 3 & Tsondab & Sandstone & Tertiary & $20-5 \mathrm{Ma}$ & TTs \\
\hline KK 1 and 2 & Karpfenkliff & Conglomerate & Neogene & $15-14 \mathrm{Ma}$ & TKk \\
\hline SS 1 and 2 & Sossus Sand & Sand & Quaternary & Modern & QSs \\
\hline EG 1 and 2 & Donkerhuk & Granite & Cambrian & $\pm 575-523 \mathrm{Ma}$ & EgDh \\
\hline KS 3 and 4 & Kuiseb & Schist & Precambrian & $\pm 880-460 \mathrm{Ma}$ & NKs \\
\hline \multicolumn{6}{|l|}{ River } \\
\hline HM 1 and 2 & Homeb & Silt & Quaternary & Recent & QHm \\
\hline GB & Gobabeb & Gravel & Quaternary & Recent & QGb \\
\hline
\end{tabular}

instructions. 16S rRNA gene PCR amplification was performed using the primer set E9F: 5'-GAGTTTGATCCTGGCTCAG-3' (Hansen et al., 1998)/ U1510R: 5'-GGTTACCTTGTTACGACTT-3' (Reysenbach \& Pace, 1995). For T-RFLP analysis, the forward primer E9F was $5^{\prime}$-end FAM labelled. KAPA2 $\mathrm{G}^{\mathrm{TM}}$ Robust (Kapa Biosystems, South Africa) was used for the amplifications and the PCR mixtures contained $1 \times$ Buffer, $1 \times$ Enhancer, $0.7 \mu \mathrm{M}$ of each primer, 5\% DMSO, $200 \mu \mathrm{M}$ of each dNTP (Fermentas, USA) and $0.5 \mathrm{U}$ of DNA polymerase. PCR conditions entailed a 3 -min denaturation step at $95{ }^{\circ} \mathrm{C} ; 25$ to 35 cycles of $95^{\circ} \mathrm{C}$ for 30 s, $55^{\circ} \mathrm{C}$ for $30 \mathrm{~s}$ and $72{ }^{\circ} \mathrm{C}$ for $90 \mathrm{~s}$; and a 10 -min final elongation step. PCR products were purified with the NucleoSpin ${ }^{\circledR}$ Gel and PCR Clean-up kit (Macherey-Nagel, GmbH \& Co. KG, Düren, Germany) and $200 \mathrm{ng}$ purified PCR amplicons were digested overnight with HaeIII (Fermentas, USA). The restriction digests were purified with the NucleoSpin ${ }^{\circledR}$ Gel and PCR Clean-up kit (Macherey-Nagel, GmbH \& Co. KG, Düren, Germany), prior to capillary electrophoresis at the Central Analytical Facilities of the University of Stellenbosch (South Africa). T-RFLP data were analysed using Peak Scanner ${ }^{\mathrm{TM}}$ Software vl.0 (Applied Biosystems) and T-REX (Culman et al., 2009). The method developed by Abdo et al. (2006) was used for filtering noise (using a standard deviation of 2 ) and binning the peaks into Operational Taxonomic Units (OTU).

\section{Statistical analyses}

Prior to analysing the edaphic bacterial community structures in the Central Namib Desert samples, the physicochemical and biological data sets were considered separately. A principal component analysis (PCA) of the normalised environmental data set was performed using PRIMER 6 (Clarke, 1993) to assess the dominating environmental gradients. Plots of the correlation circles for the environmental variables were produced with the FactoMineR package in R (Le et al., 2008). The T-RFLP data set was the presence-absence transformed and utilised for a multidimensional scaling analysis (MDS) in PRIMER 6 applying Bray-Curtis distance coefficients. The presenceabsence data were used instead of abundance data to minimise the effect of biases related (i) to varying total DNA extraction efficiencies with regards to soil characteristics (Martin-Laurent et al., 2001) and (ii) to PCR amplification biases (and particularly the preferred amplification of specific bacterial 16S rRNA sequences; Kanagawa, 2003). Venn diagrams displaying unique and shared OTUs among the different terrain types were produced with the gplots package in R (Warnes et al., 2013). Subsequently, environmental characteristics and bacterial community fingerprint data were combined in a redundancy analysis (RDA) to identify environmental drivers potentially shaping the edaphic bacterial assemblages. Analyses were performed in $\mathrm{R}$ ( $\mathrm{R}$ Core Team, 2013) and environmental parameters that significantly contributed in explaining the biological variation were selected using the 'step' function in vegan (Oksanen et al., 2013).

To screen for overall and pairwise differences between the terrain types and geologic units, a permutational multivariate analysis of variance (PERMANOVA) was performed using ADONIS in VEGAN (Oksanen et al., 2013). ADONIS analysis variances were obtained using distance matrices, which were created using Euclidean distances for the environmental variables and Bray-Curtis dissimilarities for the T-RFLP presence-absence data set. Betadisper was used to investigate the homogeneity of the group variances, and ANOVA was used to determine whether these differed significantly. Subsequently, the Tukey's Honest Significant Difference method was used to identify which of the groups differed in variance. Results were used to re-interpret the ADONIS outcome. Graphical representations were realised under $\mathrm{R}$ software ( $\mathrm{R}$ Core Team, 2013), and 
analyses were performed using the package VEGAN (Oksanen et al., 2013).

\section{RESULTS}

\section{Physicochemical characterisation of the surface materials}

The first two axes of the PCA explain $57 \%$ of the variability among the samples based on the 30 environmental descriptors recorded (Fig. 2A). There is a strong separation along the first axis of the KS4 samples, which represent higher N, $\mathrm{P}$ and metal concentrations (Table S1). KS4 and its replicate site KS3 were subsequently eliminated from the analysis to avoid skewing of the plot by the strong metal gradient.

The resulting PCA is presented in Fig. 2B, where axis one accounts for $31 \%$ of the variation and separates the three desert terrain types (dune, gravel plain and ephemeral river). The Gobabeb Gravel river samples (GB), which are situated among the gravel plain samples, are an exception to this otherwise logical clustering. The first axis is strongly correlated with grain size, CEC, moisture content, and $\mathrm{Cd}, \mathrm{Cu}, \mathrm{Mg}, \mathrm{Ca}$ and $\mathrm{Mn}$ concentrations (Fig. 2C-E).

The dune sites are characterised by their larger grain size and low concentrations of nutrients, anions and metals, and cluster closely together on the PCA plot. This indicates low heterogeneity in their overall physicochemistry (Fig. 2B), a result confirmed by the Betadisper analysis (Fig. 3A). The dune samples are distinct from both gravel plain and ephemeral river samples (ADONIS $P=0.001$; Table S2). However, the significant difference from the gravel plain sites as indicated by the ADONIS analysis might be due to the large difference in intraterrain-type variability observed for the gravel plains (Tukey $P<0.05$, Table S2; Fig. 3A).

The samples from the ephemeral river do not form a cluster and are not significantly different from the gravel plain samples (Table S2). This is probably due to the Gobabeb Gravel (GB) samples, which present physicochemist-
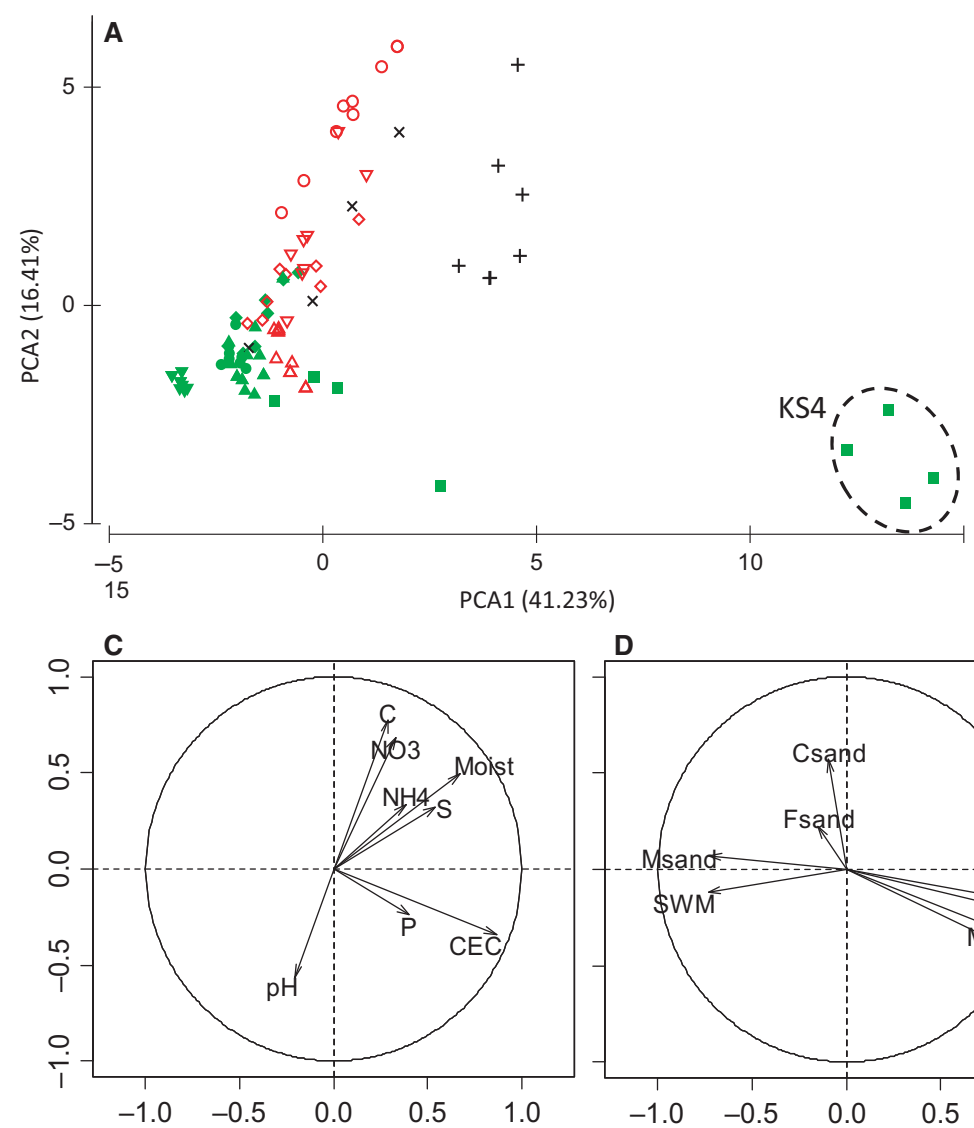

D

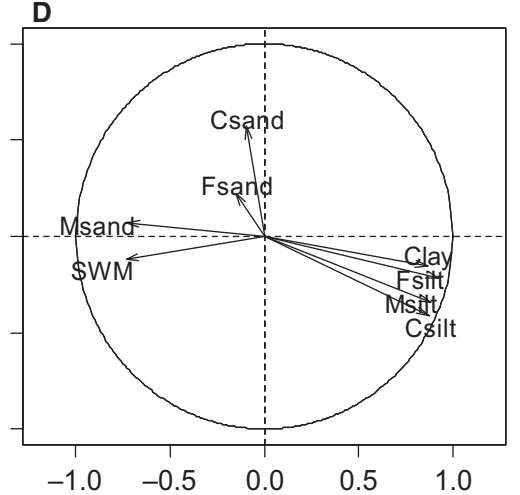

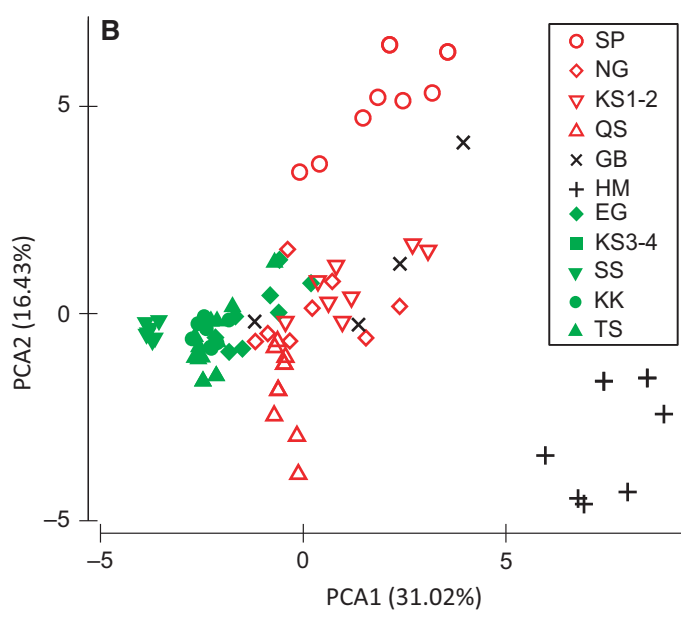

E

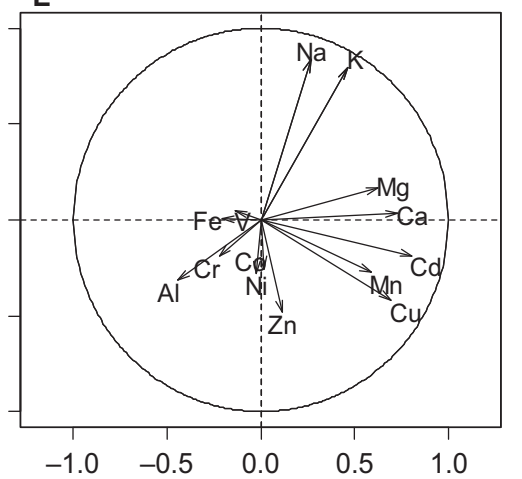

Fig. 2 Results of the Principal Component Analyses (PCA) using the 30 recorded desert soil variables. (A) Ordination plot for the analysis of all sites sampled indicating the positioning of the KS4 samples. (B) Ordination plot for the analysis of the sites excluding the high metal samples (KS3\&4, Table S1). (C, D \& E) Relationships between the environmental variables with the first two PCA axes when leaving out the sites KS3\&4 (B). The variables have been split over three separate correlation circles for clarity reasons and display: (C) the general descriptors, (D) the soil texture parameters, and (E) the cations, heavy metals and trace elements (abbreviations in Table S1). Soil samples are grouped by replicates and terrain-type are colour coded with Gravel Plains in red, Dunes in green, and River in black. The site codes and geological characterisation are described in Table 1. 

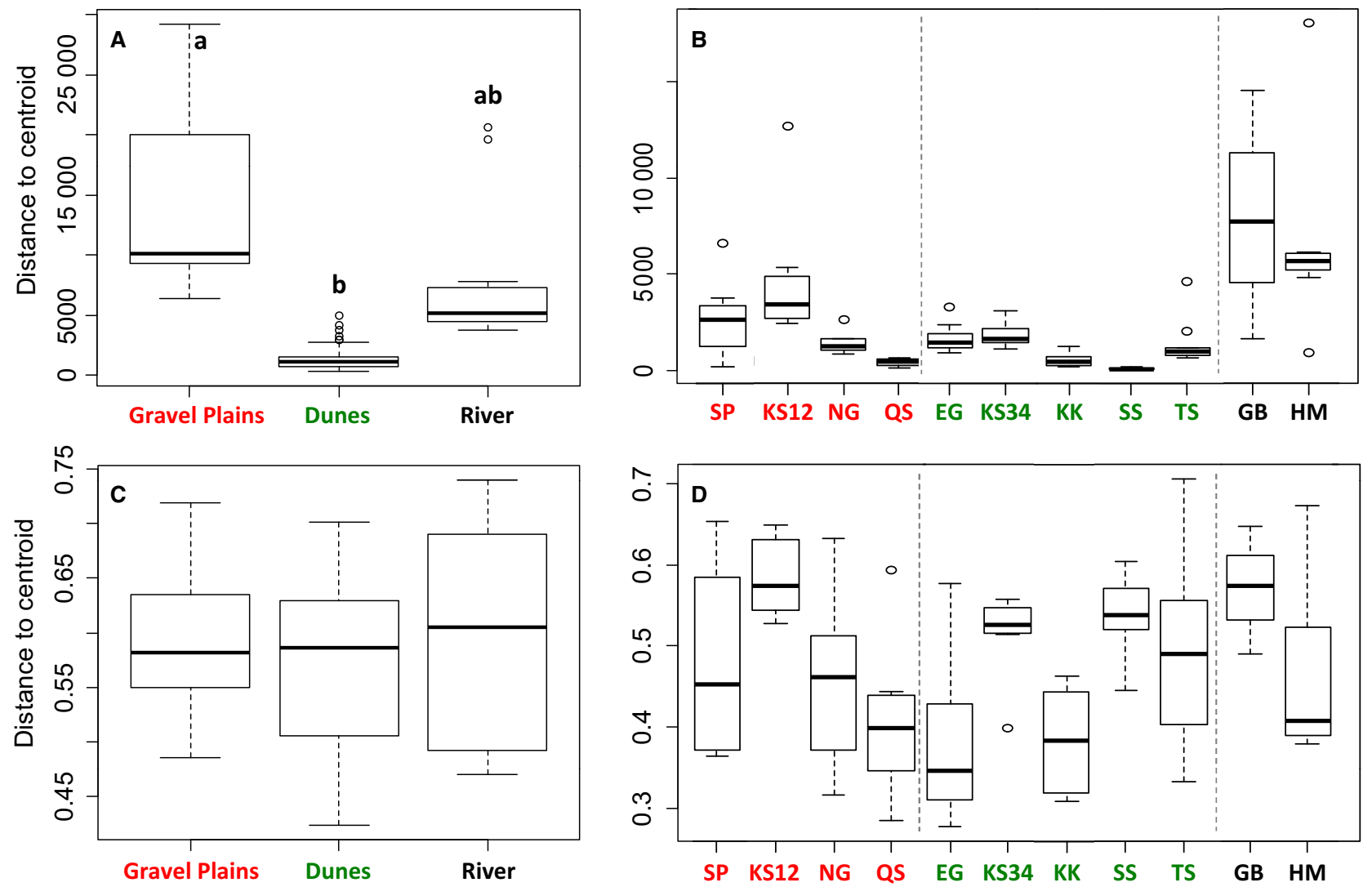

Fig. 3 Boxplots representing the Betadisper analyses displaying the homogeneity of group variances as the distance to the centroid. (A \& B) boxplots for the environmental variables showing $(A)$ the results for all samples grouped per environment and (B) the results for all samples grouped per geological unit. (C \& D) boxplots for the T-RFLP presence-absence data showing (C) the results for all samples grouped per environment and (D) the results for all samples grouped per geological unit. For site codes and grouping of sites by environment see Table 1. Different letters indicate significant differences $(P<0.05)$ in the homogeneity of group variances (Tukey test, Table S2). Results are colour coded per environment; Gravel Plains (red), Dunes (green), and River (black).

ries close to those of the gravel plain soils (Table S1). The Homeb Silt river samples (HM) separate from all others based on their small grain size, a large CEC and high values for $\mathrm{Cu}, \mathrm{Cd}, \mathrm{Mn}, \mathrm{Ca}, \mathrm{Mg}$ and $\mathrm{P}$.

The gravel plain sites occupy an intermediate position on the first axis, and there is a large variability in their overall environmental characteristics (Figs $2 \mathrm{~B}$ and $3 \mathrm{~A}$ ). The geological units from the gravel plain separate along the second axis (explaining 16\% of the observed variation), which is correlated with medium grain size, nutrient levels $(\mathrm{C}, \mathrm{N}), \mathrm{pH}$, salt content $(\mathrm{Na}, \mathrm{K})$, moisture and metals $(\mathrm{Zn}, \mathrm{Ni}, \mathrm{Al}, \mathrm{Cu})$. Although the gravel plain terrain type is very heterogeneous in its general physicochemical characteristics (Fig. 3A), each geological unit is highly homogeneous (Fig. 3B). Of the gravel plain sites, the saline springs (SP) are strongly discriminated due to their high salt, moisture and nutrient levels, while the surficial cover (QS) samples are characterised by a high $\mathrm{pH}$ and high $\mathrm{Zn}, \mathrm{Ni}$ and Co concentrations.

Pairwise comparison of the different geological units indicates that the salt (SP), silt (HM) and dune (SS) sites are significantly different from all other sites based on their overall environmental conditions (with the exception of HM vs. KS1\&2; Table S3). For the other geological units (including the high metal containing sites KS3\&4), patterns seem more random. Results suggest that GB differs from most other sites, although the high intrageologicalunit variability in environmental conditions might influence the ADONIS analyses (Tukey $P>0.05$; Table S3).

Overall, the results suggest that the grain size gradient is important in separating the three desert terrain types. In addition, the gravel plain surface soil is very heterogeneous in nature, but consists of homogeneous geological units, while the salt, silt and dune soils constitute specific surface soil types.

\section{Namib Desert edaphic bacterial community fingerprinting}

T-RFLP analysis yielded a total of 173 OTUs from the Central Namib Desert soils, ranging from 14 (GB) to 72 (KS1\&2) per geological unit sampled (Fig. 4). Comparable and high OTU richness was observed in the saline springs 
Fig. 4 Multi-Dimensional Scaling (MDS) plot using the Bray-Curtis dissimilarity matrix of bacterial community structures based on $16 \mathrm{~S}$ rRNA gene T-RFLP presence-absence profiles. The samples are grouped by geological unit and colour coded per terrain type (Gravel Plains in red, Dunes in green, and River in black. Site codes are described in Table 1). Inset: Venn diagram showing the number of shared among the three environments. $\mathrm{N}$ indicates the total number of OTUs detected in a given environment (venn diagram) or geological unit (MDS legend). OTUs unique to each soil environment and

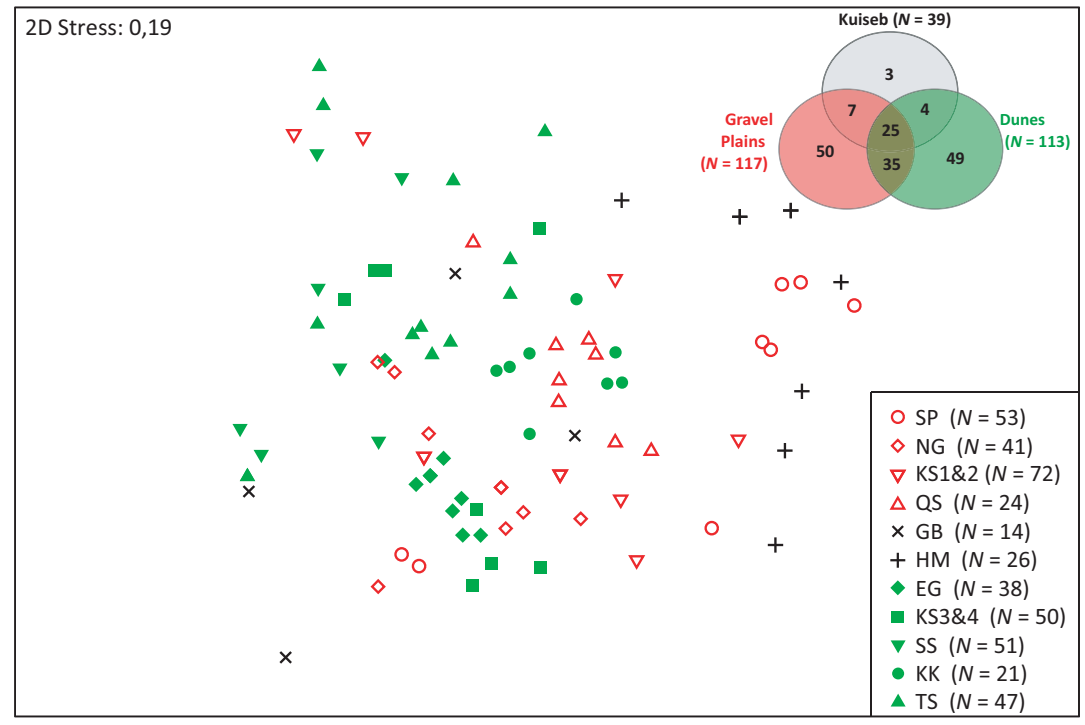

(SP; $\mathrm{N}=53$ ), high metal sites (KS3\&4; $\mathrm{N}=50)$ and sand sea samples ( $S S ; \mathrm{N}=51$ ). The MDS plot (Fig. 4) shows no distinct separation of the bacterial communities in the different desert terrain types based on the T-RFLP profiles, as confirmed by the high stress value. ADONIS, however, indicated significant overall and pairwise differences between the three terrains and between 47 of the 55 geologic-unit-pairs (Tables S2 \& S3). The gravel plain and the dune samples presented similar numbers of total and unique OTUs, and shared many of their OTUs. The ephemeral river, where only two geological units were sampled, contains a lower number of OTUs, of which the majority are shared with the two other terrain types. These observations might explain the large overlap of the samples from the different terrain types in the MDS plot. In addition, the results from the MDS and the Betadisper analyses (Fig. 3C,D) reveal great intrasample variability among samples from a given terrain and geological unit.

These findings suggest a high level of local spatial heterogeneity of the desert soil bacterial communities. In addition, the large degree of overlap among sites differs from the patterns observed in the physicochemical analyses.

\section{Environmental drivers of the Namib Desert edaphic bacterial community structures}

Ten variables were identified by stepwise model building as contributing significantly $(P<0.05)$ to the variance in the T-RFLP data set: fine silt, medium and fine sand content, $\mathrm{pH}, \mathrm{S}, \mathrm{Na}, \mathrm{Zn}, \mathrm{Al}, \mathrm{V}$ and $\mathrm{Fe}$ concentrations. $40 \%$ of the total variance can be explained by these constraining variables, with the first two axes explaining $69.4 \%$ of this variation (Fig. 5).

There is no clear grouping of soil samples by terrain type on the RDA plot. However, three clusters of samples can be distinguished visually (indicated by ellipses in

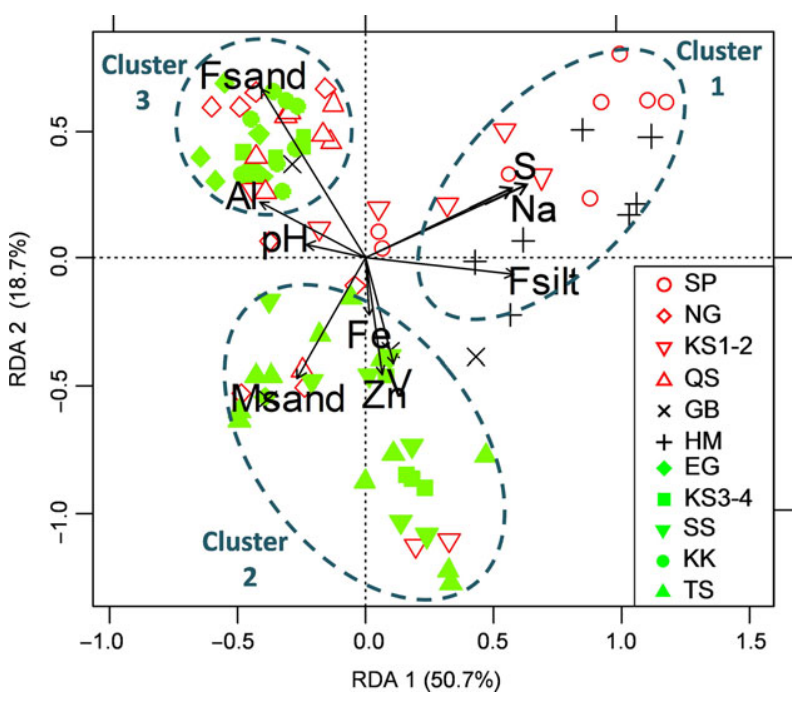

Fig. 5 Redundancy Analysis (RDA) ordination plot; displaying the Namib Desert edaphic bacterial communities and the relationships with the ten significant environmental variables. The samples are grouped by geological unit and colour coded per environment; Gravel Plains (red), Dunes (green), and River (black) (site codes see Table 1). The ellipses indicate the visually identified clusters which are discussed in the results section.

Fig. 5). Cluster 1 contains the Homeb Silt (HM) and saline spring (SP) samples. The bacterial community structures at these sites are driven by small grain size, that is silt (HM, Table S1), and high $\mathrm{Na}$ and $\mathrm{S}$ concentrations (SP, Table S1). Cluster 2 consists mainly of samples from the dune terrain; that is the dune slope (SS), the Tsondab Sandstone interdune (TS) and the high metal containing KS4 samples. At these sites, the bacterial community structures are related to medium sand grains (SS \& TS; Table S1) and high V (TS), $\mathrm{Zn}$ and Fe (KS4) concentrations. Cluster 3 contains mostly gravel plain and dune samples 
(EG, KS3, KK and QS) with fine sand, high Al levels and higher $\mathrm{pH}$ values identified as significant drivers of their bacterial community structures.

Constraining the T-RFLP data with the environmental drivers reveals sample clustering which differs from the pattern observed in the PCA analysis and the lack of clustering in the MDS plot.

\section{DISCUSSION}

The Namib Desert is characterised by a strong xeric stress gradient, with an increasing frequency of precipitation and a decreasing frequency of fog events from west to east, and a central hyperarid zone (Eckardt et al., 2013b). As moisture is a major driver of desert edaphic bacterial communities (Wichern \& Joergensen, 2009; Stomeo et al., 2013), this study was performed only within the 'fog zone' to minimise climatological influences.

\section{Central Namib Desert soil surface physicochemistry}

The area north of the GRTC and the Kuiseb River (i.e. the gravel plains) is home to the oldest rocks in the area; largely Precambrian schist (KS) and a series of related low relief $(<5 \mathrm{~m})$ outcrops, including Cambrian Salem granites $(\mathrm{NG})$. These outcrops are only partially covered by a thin $(<2 \mathrm{~m})$ surficial lag $(\mathrm{QS})$, rich in calcium carbonate to the east and gypsum to the west, and may incorporate modern day saline spring deposits (SP) linked to ephemeral drainage lines. The area south of the GRTC and the Kuiseb River is both younger and more dynamic, dominated by active dunes (approx. $50 \mathrm{~m}$ high), sandstone and conglomerates which, with a few exceptions, cover much of the schists and granites. The interdune corridors consist largely of the Tertiary Tsondab Sandstone (TS) and the younger calcified Karpfenkliff Conglomerate (KK), both of which feature a thin sandy cover. The present day Namib Sand Sea (SS) only partially covers the TS and KK. Very localised outcrops of both schist (NK) and granite (EG) can be found in some interdune corridors close to the Kuiseb River. The Kuiseb River itself is home to contemporary river sediments which are flanked by a series of young terraces that include the Homeb Silts (HM) and Gobabeb gravels (GB). Of the 30 edaphic variables measured, soil texture was the main characteristic distinguishing the three Central Namib Desert terrain types investigated, that is the ephemeral river, the gravel plains and the dune sand sea.

The Namib Desert gravel plain terrain was found very heterogeneous and to consist of distinctive geological units. This terrain type is subjected to weathering, mostly under the influence of processes controlled by water, moisture and temperature cycles (Viles \& Goudie, 2013). However, it is characterised by very stable, old surfaces on which only the strongest winds have an influence (Eckardt et al., 2013a). Our results confirmed that the gravel plains surface soils were generally stable with low disturbance and admixtures, as each geologic unit studied presented a specific physicochemical signature.

The dune sites, however, formed a particularly distinct and highly homogeneous terrain type based on the physicochemical data. In contrast with the gravel plains, the strong influence of the wind in shaping the dune terrain (Eckardt et al., 2013a) is likely to result in considerable mixing of the different surface soils and could explain the large homogeneity in physicochemical characteristics among the different sites studied.

Contrastingly, the samples from the ephemeral river did not form a homogeneous cluster in the PCA analyses. Although both the HM and GB samples were composed of recent deposits associated with the Kuiseb River channel, they differ in origin; that is silt deposits and incised conglomerates, respectively (Eckardt et al., 2013a). Our results clearly demonstrate that these differences in origin have led to significant physicochemical differences. However, only two river-associated lithologies were sampled. The low number of Gobabeb Gravel samples, in combination with the large variance in environmental conditions (Fig. 3B), confirmed that this geological unit was undersampled. Therefore, and to further test its heterogeneity, a more exhaustive Namib Desert riverine sample set should in the future be studied.

\section{Namib Desert edaphic bacterial community drivers}

Soil physicochemical properties play an important role in shaping microbial communities in oligotrophic desert environments (Makhalanyane et al., 2015). However, and in contrast to soil physicochemistry, the Namib Desert edaphic bacterial community structures in the gravel plains, sand dunes and river soils did not exhibit clear distinctive patterns and were found rather heterogeneous.

Spatial heterogeneity in bacterial community composition has previously been described in other hot desert edaphic environments (e.g. Direito et al., 2011; Ehrenfreund et al., 2011; Gonzalez-Martin et al., 2013). In the Utah Desert for example, open soil bacterial communities displayed spatial heterogeneity with large differences in community structure over very small $(\mathrm{cm})$ distances (Direito et al., 2011; Ehrenfreund et al., 2011; Kotler et al., 2011). In such open soil environments, the heterogeneous distribution of minerals can create spatial variability in microhabitats and in (bio)available chemical elements. This has been observed in a culture-dependant study on dune sand grains from the Merzouga Desert (Morocco), where bacterial diversity was found related to different mineralogies (Gommeaux et al., 2010). Carson et al. (2009) suggested that the patchwork distribution of different minerals 
in open soils may add to the spatial heterogeneity of bacterial communities. For instance, in nutrient poor environments such as desert soils, minerals that represent (a) nutrient source(s) might be preferentially colonised than minerals of poor nutrient content (Carson et al., 2009). This implies that the spatial heterogeneity in edaphic microbial community composition could be related to the spatial heterogeneity in soil mineral content and distribution; a parameter that should further be investigated in microbial ecology studies of oligotrophic desert soils.

Overall, ten physicochemical drivers were able to explain a large portion of the total variation $(40 \%)$ present in the biological dataset; corresponding to a combination of soil structure and very local and specific environmental conditions (i.e. fine silt, medium and fine sand content, $\mathrm{pH}, \mathrm{S}$, $\mathrm{Na}, \mathrm{Zn}, \mathrm{Al}, \mathrm{V}$ and $\mathrm{Fe}$ concentrations). This implies that (a combination of) other (a)biotic factors (e.g. unmeasured soil physicochemical variables and/or microbial interactions) could be governing Namib Desert soil community patterns. However, this result is strong as such percentages of total variation are not to our knowledge commonly observed; particularly in arid soil systems. Indeed, in a similar RDA-based analyses on hyperarid Antarctic communities, $18 \%$ of their variation was explained by three of the eight measured variables (NO3, F, S; Makhalanyane et al., 2013). Correlation analyses characterised soil \%Silt, $\mathrm{pH}$, $\mathrm{EC}, \mathrm{CEC}$ and \%C in the Sonoran desert and water availability and salt contents in the Atacama desert to be crucial factors in shaping edaphic communities analysed by pyrosequencing (Andrew et al., 2012; Crits-Christoph et al., 2013). In a T-RFLP-based study, it was found soil texture, and organic and water content to be significantly correlated with the edaphic community structures in various arid and Mediterranean regions of Israel (Pasternak et al., 2013). However, these correlation studies measured a limited number $(\leq 16)$ of edaphic variables in a maximum of 6 sites, while we recorded thirty variables for 22 sites. Overall, this strongly suggests that, independently from the molecular tool used, to properly determine factors shaping desert edaphic communities structures an holistic characterisation of the soil physicochemistries is crucial as local soil environmental factors appear to be determinants in microbial community assembly (Pasternak et al., 2013).

The RDA analysis identified grain size as the major driver of edaphic bacterial communities in the Central Namib Desert, as observed in other soil bacterial communities (e.g. Wichern \& Joergensen, 2009; Dequiedt et al., 2011; Ehrenfreund et al., 2011). Our results indicate that the small grain size Homeb Silt (HM) soils harbour bacterial communities similar to those of the saline deposits (SP). Salinity and conductivity have also already been identified as influencing bacterial community composition in desert environments (Cary et al., 2010; Zeglin et al., 2011; Andrew et al., 2012; Lee et al., 2012; Geyer et al., 2013).
High salt concentrations, by reducing the water (bio)availability and increasing osmotic pressure, have been shown to negatively influence microbial richness and diversity in desert soils (Zeglin et al., 2011; Stomeo et al., 2013; Van Horn et al., 2013). We observed high moisture content and high OTU richness in the saline deposit samples. The high moisture content is due to the fact that the saline deposits exist in areas of shallow groundwater flow, which is known to follow the $1 \%$ slope of the gravel plains, surface and evaporate (Eckardt et al., 2013b and references therein). We suspect that the higher OTU richness at these sites might be due to the positive effect of increased moisture levels on bacterial abundance and diversity (Clark et al., 2009; Maienza \& Baath, 2014). Contrastingly, the generally low number of OTUs detected in the river environment was surprising, as it has been previously found positive correlations between microbial biomass and CEC, clay and fin silt contents; all of which were high in this environment (Table S1; Dequiedt et al., 2011). And, fine textured soils have also been found to harbour microbial communities with high diversities (Torsvik \& Ovreas, 2002). This probably results from the fact that DNA extractions from high clay containing soils yield low amounts due to high absorption of DNA molecules on clay minerals (Yu et al., 2013).

Several metals defined the clustering of edaphic bacterial communities identified in the RDA (Fe, $\mathrm{V}$ and $\mathrm{Zn}$ for cluster 2, Al for cluster 3; Fig. 5). Elevated concentrations of (heavy) metals can also represent an additional stress for bacteria, decreasing diversity and altering community structures (Ramond et al., 2009). We noted that samples showing high metal concentrations (KS3\&4) did not necessarily show a lower OTU richness as compared to the other sites (Fig. 4), nor did the high metal content sites form a distinct cluster in either the MDS or RDA ordinations (Figs 4 and 5 , respectively). Of the metals identified as significant drivers in the RDA analysis, Fe and $\mathrm{V}$ were only weakly related to the first two axes of the PCA, and thus of minor importance when characterising the sites physicochemically (Fig. 2C). However, both metals had significant influence on the edaphic bacterial community structures stressing the importance of recording a wide variety of environmental descriptors; including those that do not appear to represent distinct gradients based on physicochemistry alone.

Species sorting, the process in which the environment selects for a restricted subset of the metacommunity, could explain the observed disparity between desert terrain soil homogenous' physicochemestries and bacterial communities' general heterogeneity. It has already been observed as a mechanism of community development in extreme environments (e.g. Lee et al., 2012; Geyer et al., 2013; Van Horn et al., 2013). This process could notably explain why the more distinct geological units (high salt content (SP), high metal concentrations (KS3\&4), small grain size 
(HM), large grain size (SS)) did not display discrete communities (Lee et al., 2012). Similarly, in the dune habitats, where both edaphic physicochemistries and bacterial community structures were found highly consistent, wind-mediated dispersal could be important in explaining the assembly of homogenous microbial communities (Nemergut et al., 2013).

\section{CONCLUSION}

To conclude, this work sets strong foundation for future (desert) soil microbial ecology studies. It particularly demonstrated that no a priori selection of abiotic variable to measure should be made, as variables that were not identified as environmental descriptors of specific terrains were found to have a role in shaping Namib Desert edaphic bacterial communities. However, molecular fingerprinting (as used here) only enables access to the dominant phylotypes present in environmental microbial communities (Griffiths et al., 2011). Therefore, a similar study using highthroughput sequencing technologies would be beneficial to better understand/define the roles of desert soil physicochemestries in community members (Lee et al., 2012), by revealing more subtle community differences among the different geological units and/or terrain types. Moreover, it would access rare microbial taxa which have notably been shown to perform essential ecosystem functions (Shade et al., 2012) and to constitute sources of functional redundancy (Caron \& Countway, 2009).

\section{ACKNOWLEDGMENTS}

The authors would like to thank the Soil, Water and Plant Analysis Laboratory of the University of Pretoria for their help with the physicochemical analyses of the surface soil samples. The University of Pretoria and the South African National Research Foundation (NRF) are acknowledged for funding. The authors declare no conflict of interests.

\section{REFERENCES}

Abdo Z, Schuette UME, Bent SJ, Williams CJ, Forney LJ, Joyce P (2006) Statistical methods for characterizing diversity of microbial communities by analysis of terminal restriction fragment length polymorphisms of 16S rRNA genes. Environmental Microbiology 8, 929-938.

Aislabie JM, Jordan S, Barker GM (2008) Relation between soil classification and bacterial diversity in soils of the Ross Sea region, Antarctica. Geoderma 144, 9-20.

An S, Couteau C, Luo F, Neveu J, Dubow MS (2013) Bacterial diversity of surface sand samples from the Gobi and Taklamaken Deserts. Microbial Ecology 66, 850-860.

Andrew DR, Fitak RR, Munguia-Vega A, Racolta A, Martinson VG, Dontsova K (2012) Abiotic factors shape microbial diversity in Sonoran Desert soils. Applied and Environmental Microbiology 78, 7527-7537.
Ben-David EA, Zaady E, Sher Y, Nejidat A (2011) Assessment of the spatial distribution of soil microbial communities in patchy arid and semi-arid landscapes of the Negev Desert using combined PLFA and DGGE analyses. FEMS Microbiology Ecology 76, 492-503.

Borin S, Ventura S, Tambone F, Mapelli F, Schubotz F, Brusetti L, Scaglia B, D'acqui LP, Solheim B, Turicchia S, Marasco R, Hinrichs K-U, Baldi F, Adani F, Daffonchio D (2010) Rock weathering creates oases of life in a High Arctic desert. Environmental Microbiology, 12, 293-303.

Bowker MA, Belnap J (2008) A simple classification of soil types as habitats of biological soil crusts on the Colorado Plateau, USA. Journal of Vegetation Science 19, 831-840.

Bray RH, Kurtz LT (1945) Determination of total, organic, and available forms of phosphorus in soils. Soil Science 59, 39-45.

Caron DA, Countway PD (2009) Hypotheses on the role of the protistan rare biosphere in a changing world. Aquatic Microbial Ecology 57, 227-238.

Carson JK, Campbell L, Rooney D, Clipson N, Gleeson DB (2009) Minerals in soil select distinct bacterial communities in their microhabitats. FEMS Microbiology Ecology 67, 381-388.

Cary SC, Mcdonald IR, Barrett JE, Cowan DA (2010) On the rocks: the microbiology of Antarctic Dry Valley soils. Nature Reviews Microbiology 8, 129-138.

Chen R, Zhang Y, Li Y, Wei W, Zhang J, Wu N (2009) The variation of morphological features and mineralogical components of biological soil crusts in the Gurbantunggut Desert of Northwestern China. Environmental Geology 57, 1135-1143.

Clark JS, Campbell JH, Grizzle H, Acosta-Martinez V, Zak JC (2009) Soil microbial community response to drought and precipitation variability in the Chihuahuan Desert. Microbial Ecology 57, 248-260.

Clarke KR (1993) Nonparametric multivariate analyses of changes in community structure. Australian Journal of Ecology 18, 117143.

Crits-Christoph A, Robinson CK, Barnum T, Fricke WF, Davila AF, Jedynak B, McKay CP, DiRuggiero J (2013) Colonisation patterns of soil microbial communities in the Atacama Desert. Microbiome 1, 28.

Culman SW, Bukowski R, Gauch HG, Cadillo-Quiroz H, Buckley DH (2009) T-REX: software for the processing and analysis of T-RFLP data. BMC Bioinformatics 10, 171.

Dequiedt S, Saby NPA, Lelievre M, Jolivet C, Thioulouse J, Toutain B, Arrouays D, Bispo A, Lemanceau P, Ranjard L (2011) Biogeographical patterns of soil molecular microbial biomass as influenced by soil characteristics and management. Global Ecology and Biogeography 20, 641-652.

Direito SOL, Ehrenfreund P, Marees A, Staats M, Foing B, Roling WFM (2011) A wide variety of putative extremophiles and large beta-diversity at the Mars Desert Research Station (Utah). International Journal of Astrobiology 10, 191-207.

Drees KP, Neilson JW, Betancourt JL, Quade J, Henderson DA, Pryor BM, Maier RM (2006) Bacterial community structure in the hyperarid core of the Atacama Desert, Chile. Applied and Environmental Microbiology 72, 7902-7908.

Eckardt FD, Livingstone I, Seely M, Von Holdt J (2013a) The surface geology and geomorphology around Gobabeb, Namib Desert, Namibia. Geografiska Annaler: Series A, Physical Geography 95, 271-284.

Eckardt FD, Soderberg K, Coop LJ, Muller AA, Vickery KJ, Grandin RD, Jack C, Kapalanga TS, Henschel J (2013b) The nature of moisture at Gobabeb, in the central Namib Desert. Journal of Arid Environments 93, 7-19. 
Eckert D, Sims JT (1995) Recommended soil $\mathrm{pH}$ and lime requirement tests. In Recommended Soil Testing Procedures for the Northeastern United States (eds Smims JT, Wolf A). University of Delaware, Newark, DE, pp. 16-18.

Ehrenfreund P, Roling WFM, Thiel CS, Quinn R, Sephton MA, Stoker C, Kotler JM, Direito SOL, Martins Z, Orzechowska GE, Kidd RD, Van Sluis CA, Foing BH (2011) Astrobiology and habitability studies in preparation for future Mars missions: trends from investigating minerals, organics and biota. International Journal of Astrobiology 10, 239-253.

Garcia-Pichel F, Lopez-Cortes A, Nubel U (2001) Phylogenetic and morphological diversity of cyanobacteria in soil desert crusts from the Colorado Plateau. Applied and Environmental Microbiology 67, 1902-1910.

Geyer KM, Altrichter AE, Van Horn DJ, Takacs-Vesbach CD, Gooseff MN, Barrett JE (2013) Environmental controls over bacterial communities in polar desert soils. Ecosphere, 4, $\operatorname{art} 127$.

Gommeaux M, Barakat M, Montagnac G, Christen R, Guyot F, Heulin T (2010) Mineral and bacterial diversities of desert sand grains from south-east Morocco. Geomicrobiology Journal 27, 76-92.

Gonzalez-Martin C, Teigell-Perez N, Lyles M, Valladares B, Griffin DW (2013) Epifluorescent direct counts of bacteria and viruses from topsoil of various desert dust storm regions. Research in Microbiology 164, 17-21.

Griffiths RI, Thomson BC, James P, Bell T, Bailey M, Whiteley AS (2011) The bacterial biogeography of British soils. Environmental Microbiology 13, 1642-1654.

Hansen MC, Tolker-Nielsen T, Givskov M, Molin S (1998) Biased 16S rDNA PCR amplification caused by interference from DNA flanking the template region. FEMS Microbiology Ecology 26, 141-149.

Kanagawa T (2003) Bias and artifacts in multitemplate polymerase chain reactions (PCR). Journal of Bioscience and Bioengineering 96, 317-323.

Keeney DR, Nelson DW (1982) Nitrogen - inorganic forms. In Methods of Soil Analysis. Part 2. Chemical and Microbiological Properties (ed. Norman AG). American Society of Agronomy, Inc, Madison, WI, pp. 643-698.

Kotler JM, Quinn RC, Foing BH, Martins Z, Ehrenfreund P (2011) Analysis of mineral matrices of planetary soil analogues from the Utah Desert. International Journal of Astrobiology 10, 221-229.

Kutovaya OV, Vasilenko ES, Lebedeva MP (2012)

Microbiological and micromorphological characteristics of extremely arid desert soils in the Ili Depression (Kazakhstan). Eurasian Soil Science 45, 1147-1158.

Le S, Josse J, Husson F (2008) FactoMineR: An R package for multivariate analysis. Journal of Statistical Software 25, 1-18.

Lee CK, Barbier BA, Bottos EM, Mcdonald IR, Cary SC (2012) The Inter-Valley Soil Comparative Survey: the ecology of Dry Valley edaphic microbial communities. ISME Journal 6, $1046-$ 1057.

Lombard N, Prestat E, Van Elsas JD, Simonet P (2011) Soilspecific limitations for access and analysis of soil microbial communities by metagenomics. FEMS Microbiology Ecology 78, $31-49$.

Maienza A, Baath E (2014) Temperature effects on recovery time of bacterial growth after rewetting dry soil. Microbial Ecology $68,818-821$.

Makhalanyane TP, Valverde A, Birkeland NK, Cary SC, Tuffin IM, Cowan DA (2013) Evidence for successional development in Antarctic hypolithic bacterial communities. ISME Journal 7, 2080-2090.

Makhalanyane TP, Valverde A, Gunnigle E, Frossard A, Ramond J-B, Cowan DA (2015) Microbial ecology of hot desert edaphic systems. FEMS Microbiology Reviews, 39, 203-221.

Martin-Laurent F, Philippot L, Hallet S, Chaussod R, Germon JC, Soulas G, Catroux G (2001) DNA extraction from soils: old bias for new microbial diversity analysis methods. Applied and Environmental Microbiology 67, 2354-2359.

Nelson DW, Sommers LE (1982) Total carbon, organic carbon, and organic matter. In Methods of Soil Analysis. Part 2. Chemical and Microbiological Properties (ed. Norman AG). American Society of Agronomy, Inc, Madison, WI, pp. 539-579.

Nemergut DR, Schmidt SK, Fukami T, O’Neill SP, Bilinski TM, Stanish LF, Knelman JE, Darcy JL, Lynch RC, Wickey P, Ferrenberg S (2013) Patterns and processes of microbial community assembly. Microbiology and Molecular Biology Reviews 77, 342-356.

Oksanen J, Blanchet FG, Kindt R, Legendre P, Minchin PR, O'hara RB, Simpson GL, Solymos P, Stevens MHH, Wagner H (2013) vegan: Community Ecology Package. R package version 2.0-8. http://CRAN.R-project.org/package=vegan.

Pasternak Z, Al-Ashhab A, Gatica J, Gafny R, Avraham S, Minz D, Gillor O, Jurkevitch E (2013) Spatial and temporal biogeography of soil microbial communities in arid and semiarid regions. PLoS ONE 8, e69705.

Pietrasiak N, Johansen JR, Drenovsky RE (2011) Geologic composition influences distribution of microbiotic crusts in the Mojave and Colorado Deserts at the regional scale. Soil Biology \& Biochemistry 43, 967-974.

Pointing SB, Belnap J (2012) Microbial colonization and controls in dryland systems. Nature Reviews Microbiology 10, $551-562$.

Prestel E, Salamitou S, Dubow MS (2008) An examination of the bacteriophages and bacteria of the Namib desert. Journal of Microbiology 46, 364-372.

R Core Team (2013) R: A Language and Environment for Statistical Computing. R Foundation for Statistical Computing, Vienna, Austria.

Ramond J-B, Berthe T, Duran R, Petit F (2009) Comparative effects of mercury contamination and wastewater effluent input on Gram-negative merA gene abundance in mudflats of an anthropised estuary (Seine, France): a microcosm approach. Research in Microbiology 160, 10-18.

Reysenbach A, Pace NR (1995) Reliable amplification of hyperthermophilic archaeal I6S rRNA genes by the polymerase chain reaction. In Archaea: a laboratory manual - thermophiles (eds Robb FT, Place AR). Cold Springs Harbor Laboratoty, NY.

Rhoades JD (1982) Cation exchange capacity. In Methods of Soil Analysis. Part 2. Chemical and Microbiological Properties (ed. Norman AG). American Society of Agronomy, Inc, Madison, WI, pp. 149-157.

Shade A, Hogan CS, Klimowicz AK, Linske M, McManus PS, Handelsman J (2012) Culturing captures members of the soil rare biosphere. Environmental Microbiology 14, 2247-2252.

Southgate RI, Masters P, Seely MK (1996) Precipitation and biomass changes in the Namib Desert dune ecosystem. Journal of Arid Environments 33, 267-280.

Steven B, Gallegos-Graves LV, Belnap J, Kuske CR (2013) Dryland soil microbial communities display spatial biogeographic patterns associated with soil depth and soil parent material. FEMS Microbiology Ecology 86, 101-113. 
Stomeo F, Valverde A, Pointing SB, Mckay CP, Warren-Rhodes KA, Tuffin MI, Seely M, Cowan DA (2013) Hypolithic and soil microbial community assembly along an aridity gradient in the Namib Desert. Extremophiles 17, 329-337.

Torsvik V, Ovreas L (2002) Microbial diversity and function in soil: from genes to ecosystems. Current Opinion in Microbiology 5, 240-245.

Van Horn DJ, Van Horn ML, Barrett JE, Gooseff MN, Altrichter AE, Geyer KM, Zeglin LH, Takacs-Vesbach CD (2013) Factors controlling soil microbial biomass and bacterial diversity and community composition in a cold desert ecosystem: role of geographic scale. PLoS ONE, 8, e66103.

Viles HA, Goudie AS (2013) Weathering in the central Namib Desert, Namibia: controls, processes and implications. Journal of Arid Environments 93, 20-29.

Walkley A (1935) An examination of methods for determining organic carbon and nitrogen in soils. Journal of Agricultural Science 25, 598-609.

Warnes GR, Bolker B, Bonebakker L, Gentleman R, Liaw WHA, Lumley T, Maechler M, Magnusson A, Moeller S, Schwartz M, Vaenables B (2013) gplots: Various R programming tools for plotting data. R package version 2.12.1., http://CRAN.Rproject.org $/$ package $=$ gplots .

Wichern F, Joergensen RG (2009) Soil microbial properties along a precipitation transect in Southern Africa. Arid Land Research and Management 23, 115-126.
Yu WH, Li N, Tong DS, Zhou CH, Lin CX, Xu CY (2013) Adsorption of proteins and nucleic acids on clay minerals and their interactions: a review. Applied Clay Science 80-81, 443452 .

Zeglin LH, Dahm CN, Barrett JE, Gooseff MN, Fitpatrick SK, Takacs-Vesbach CD (2011) Bacterial community structure along moisture gradients in the parafluvial sediments of two ephemeral desert streams. Microbial Ecology 61, 543-556. 


\section{Supporting Information}

Table S1: Geographical coordinates of the centre of each site (see inset Figure 1) and environmental variables recorded for each sampling site. Values of variables are given as averages \pm standard deviations. Column two gives the number of samples per site. Row two presents the abbreviations used in the graphs. Values directly discussed in the text are underlined and in bold. The data are terrain-type colour coded, with pale red, green and grey indicating the gravel plain the sand dunes in green and the river beds, respectively.

\begin{tabular}{|c|c|c|c|c|c|c|c|c|c|c|}
\hline $\begin{array}{l}\text { Sample } \\
\text { name }\end{array}$ & $\#$ & $\begin{array}{c}\text { Geological } \\
\text { Unit }\end{array}$ & Latitude & Longitude & $\begin{array}{l}\text { Carbon (\%) } \\
\text { (C) }\end{array}$ & $\mathrm{pH}$ & CEC & $\begin{array}{l}\text { Moisture (\%) } \\
\text { (Moist) }\end{array}$ & $\begin{array}{c}\mathrm{NH}_{4}-\mathrm{N}(\mu \mathrm{g} / \mathrm{g}) \\
(\mathrm{NH} 4)\end{array}$ & $\begin{array}{c}\mathrm{NO}_{3}-\mathrm{N}(\mu \mathrm{g} / \mathrm{g}) \\
(\mathrm{NO})\end{array}$ \\
\hline \multicolumn{11}{|l|}{ Gravel Plains } \\
\hline QS1 & 4 & Surficial Cover & $-23,59812$ & 15,16132 & $0,145( \pm 0,031)$ & $\underline{8,32}( \pm 0,73)$ & $5,98( \pm 0,41)$ & $0,27( \pm 0,18)$ & $0,03( \pm 0,06)$ & $1,3( \pm 1,0)$ \\
\hline QS2 & 4 & Surficial Cover & $-23,59756$ & 15,16138 & $0,100( \pm 0,020)$ & $\underline{7,11( \pm 0,23)}$ & $5,94( \pm 0,23)$ & $0,28( \pm 0,04)$ & $0,69( \pm 1,28)$ & $1,6( \pm 1,2)$ \\
\hline SP1 & 4 & Saline Spring & $-23,51258$ & 15,00437 & $1,906( \pm 0,175)$ & $6,72( \pm 0,17)$ & $7,14( \pm 0,27)$ & $3,37( \pm 1,48)$ & $6,89( \pm 6,18)$ & $149,0( \pm 145,6)$ \\
\hline SP2 & 4 & Saline Spring & $-23,51234$ & 15,00507 & $1,211( \pm 0,424)$ & $6,17( \pm 0,13)$ & $6,50( \pm 0,79)$ & $1,83( \pm 1,22)$ & $4,72( \pm 5,15)$ & $133,0( \pm 104,9)$ \\
\hline NG1 & 4 & Salem Granite & $-23,54108$ & 15,04742 & $0,102( \pm 0,033)$ & $8,04( \pm 0,49)$ & $6,15( \pm 0,61)$ & $0,33( \pm 0,10)$ & $1,63( \pm 2,23)$ & $4,6( \pm 5,5)$ \\
\hline NG2 & 4 & Salem Granite & $-23,54001$ & 15,04809 & $0,027( \pm 0,019)$ & $6,33( \pm 0,28)$ & $5,28( \pm 1,34)$ & $0,39( \pm 0,11)$ & $1,72( \pm 2,44)$ & $58,5( \pm 60,6)$ \\
\hline KS1 & 4 & Kuiseb Schist & $-23,57604$ & 15,09856 & $0,041( \pm 0,053)$ & $7,72( \pm 0,15)$ & $6,95( \pm 1,29)$ & $0,63( \pm 0,20)$ & $3,19( \pm 3,26)$ & $78,2( \pm 66,5)$ \\
\hline KS2 & 4 & Kuiseb Schist & $-23,57513$ & 15,09861 & $0,060( \pm 0,019)$ & $6,86( \pm 0,07)$ & $6,75( \pm 1,10)$ & $0,64( \pm 0,26)$ & $1,69( \pm 1,43)$ & $62,5( \pm 48,2)$ \\
\hline Average ( \pm SD) & & & & & $0.449( \pm 0.691)$ & $7,16( \pm 0,81)$ & $6,34( \pm 0,96)$ & $0,97( \pm 1,21)$ & $2,57( \pm 3,65)$ & $61,1( \pm 84,6)$ \\
\hline Min-max & & & & & $0,000-2.075$ & $6,00-9,26$ & $3,28-8,53$ & $0,00-5,30$ & $0,00-13,91$ & $0,1-364,0$ \\
\hline \multicolumn{11}{|l|}{ Sand Sea } \\
\hline KS3 & 4 & Kuiseb Schist & $-23,52727$ & 14,99414 & $0,062( \pm 0,064)$ & $6,70( \pm 0,28)$ & $5,61( \pm 1,95)$ & $0,21( \pm 0,07)$ & $2,46( \pm 1,25)$ & $19,4( \pm 20,1)$ \\
\hline KS4 & 4 & Kuiseb Schist & $-23,52743$ & 14,99494 & $1,818( \pm 0,277)$ & $6,54( \pm 0,54)$ & $21,47( \pm 2,89)$ & $1,63( \pm 0,13)$ & $\underline{47,18( \pm 45,41)}$ & $\underline{255,6}( \pm 204,7)$ \\
\hline EG1 & 4 & Donkerhuk Granite & $-23,55411$ & 14,99717 & $0,018( \pm 0,026)$ & $7,77( \pm 1,15)$ & $6,58( \pm 0,22)$ & $0,30( \pm 0,14)$ & $0,58( \pm 0,43)$ & $32,1( \pm 64,0)$ \\
\hline EG2 & 4 & Donkerhuk Granite & $-23,55512$ & 14,99511 & $0,025( \pm 0,034)$ & $7,13( \pm 0,58)$ & $6,40( \pm 0,39)$ & $0,23( \pm 0,07)$ & $3,52( \pm 3,90)$ & $8,9( \pm 12,2)$ \\
\hline SS1 & 3 & Sossus Sand & $-23,60718$ & 15,00915 & $0,019( \pm 0,009)$ & $8,76( \pm 0,42)$ & $4,02( \pm 0,25)$ & $0,08( \pm 0,02)$ & $0,00( \pm 0,00)$ & $0,8( \pm 0,2)$ \\
\hline SS2 & 4 & Sossus Sand & $-23,53404$ & 14,99681 & $0,025( \pm 0,012)$ & $8,71( \pm 0,13)$ & $4,18( \pm 0,32)$ & $0,07( \pm 0,02)$ & $0,40( \pm 0,81)$ & $1,7( \pm 0,5)$ \\
\hline KK1 & 4 & Karpfenkliff Conglomerate & $-23,60597$ & 15,00783 & $0,065( \pm 0,030)$ & $\underline{8,06( \pm 0,61)}$ & $5,68( \pm 0,68)$ & $0,20( \pm 0,01)$ & $0,39( \pm 0,51)$ & $1,4( \pm 0,4)$ \\
\hline KK2 & 4 & Karpfenkliff Conglomerate & $-23,6091$ & 15,00862 & $0,027( \pm 0,018)$ & $7,73( \pm 0,53)$ & $5,75( \pm 0,61)$ & $0,26( \pm 0,03)$ & $0,38( \pm 0,72)$ & $1,4( \pm 0,8)$ \\
\hline TS1 & 4 & Tsonab Sandstone & $-23,57613$ & 14,98817 & $0,042( \pm 0,008)$ & $6,76( \pm 0,40)$ & $5,58( \pm 1,47)$ & $0,59( \pm 0,37)$ & $0,13( \pm 0,27)$ & $42,0( \pm 32,3)$ \\
\hline TS2 & 4 & Tsonab Sandstone & $-23,5749$ & 14,99714 & $0,045( \pm 0,006)$ & $7,29( \pm 1,00)$ & $5,75( \pm 1,03)$ & $0,26( \pm 0,08)$ & $0,78( \pm 1,24)$ & $2,0( \pm 0,4)$ \\
\hline TS3 & 4 & Tsonab Sandstone & $-23,57195$ & 14,99731 & $0,044( \pm 0,007)$ & $7,83( \pm 0,24)$ & $5,55( \pm 0,14)$ & $0,37( \pm 0,19)$ & $0,00( \pm 0,00)$ & $1,5( \pm 0,4)$ \\
\hline Average ( \pm SD) & & & & & $0,203( \pm 0,528)$ & $7,54( \pm 0,90)$ & $7,03( \pm 4,86)$ & $0,39( \pm 0,44)$ & $5,19( \pm 18,30)$ & $34,1( \pm 93,5)$ \\
\hline Min-max & & & & & $0,000-2,119$ & $6,10-9,23$ & $2,72-24,26$ & $0,05-1,75$ & $0,00-115,28$ & $0,0-477,4$ \\
\hline \multicolumn{11}{|l|}{ Kuiseb River } \\
\hline GB & 4 & Gobabeb Gravel & $-23,56525$ & 15,04346 & $0,197( \pm 0,212)$ & $7,94( \pm 0,95)$ & $7,09( \pm 2,10)$ & $1,01( \pm 1,43)$ & $10,99( \pm 7,83)$ & $144,5( \pm 200,5)$ \\
\hline HM1 & 3 & Homeb Silt & $-23,62841$ & 15,17942 & $0,188( \pm 0,006)$ & $7,10( \pm 0,14)$ & $18,24( \pm 1,09)$ & $2,45( \pm 0,61)$ & $7,42( \pm 6,02)$ & $45,0( \pm 69,4)$ \\
\hline HM2 & 4 & Homeb Silt & $-23,63153$ & 15,17867 & $0,079( \pm 0,025)$ & $8,49( \pm 0,37)$ & $18,86( \pm 1,31)$ & $1,51( \pm 0,31)$ & $0,69( \pm 0,61)$ & $2,0( \pm 1,6)$ \\
\hline
\end{tabular}




\begin{tabular}{|c|c|c|c|c|c|c|}
\hline Average ( \pm SD) & $0.152( \pm 0,130)$ & $7,91( \pm 0,81)$ & $14,41( \pm 5,98)$ & $1,59( \pm 1,04)$ & $6,27( \pm 6,89)$ & $65,5( \pm 131,4)$ \\
\hline Min-max & $0,016-0,503$ & $6,94-9,21$ & $4,02-19,88$ & $0,13-3,16$ & $0,34-20,26$ & $0,0-430,9$ \\
\hline \multicolumn{7}{|c|}{ Central Namib Desert } \\
\hline Average $( \pm S D)$ & $0,288( \pm 0,574)$ & $7,45( \pm 0,88)$ & $7,72( \pm 4,79)$ & $0,76( \pm 0,96)$ & $4,36( \pm 13,34)$ & $48,2( \pm 95,7)$ \\
\hline Min-max & $0,000-2,119$ & $6,00-9,26$ & $2,72-24,26$ & $0,00-5,30$ & $0,00-115,28$ & $0,0-477,4$ \\
\hline
\end{tabular}

\section{Table S1 (continued)}

\begin{tabular}{|c|c|c|c|c|c|c|c|c|c|}
\hline Sample & $\#$ & $\begin{array}{l}\text { Clay (\%) } \\
\text { (Clay) }\end{array}$ & $\begin{array}{l}\text { Fine silt (\%) } \\
\quad \text { (Fsilt) }\end{array}$ & $\begin{array}{l}\text { Medium silt (\%) } \\
\text { (Msilt) }\end{array}$ & $\begin{array}{c}\text { Coarse silt (\%) } \\
\text { (Csilt) }\end{array}$ & $\begin{array}{l}\text { Fine sand (\%) } \\
\text { (Fsand) }\end{array}$ & $\begin{array}{l}\text { Medium sand (\%) } \\
\text { (Msand) }\end{array}$ & $\begin{array}{c}\text { Coarse sand (\%) } \\
\text { (Csand) }\end{array}$ & $\begin{array}{c}\text { Surface weighed mean } \\
\text { (SWM) }\end{array}$ \\
\hline \multicolumn{10}{|c|}{ Gravel Plains } \\
\hline QS1 & 4 & $0,34( \pm 0,13)$ & $1,03( \pm 0,13)$ & $2,18( \pm 0,19)$ & $10,46( \pm 1,16)$ & $\underline{64,10( \pm 2,90)}$ & $15,92( \pm 1,96)$ & $5,98( \pm 2,31)$ & $49,7( \pm 28,4)$ \\
\hline QS2 & 4 & $0,29( \pm 0,20)$ & $0,97( \pm 0,22)$ & $2,12( \pm 0,28)$ & $9,27( \pm 1,55)$ & $63,78( \pm 2,44)$ & $17,11( \pm 2,27)$ & $6,45( \pm 2,36)$ & $69,8( \pm 11,4)$ \\
\hline SP1 & 4 & $1,29( \pm 0,41)$ & $2,53( \pm 0,70)$ & $3,89( \pm 0,83)$ & $6,73( \pm 0,49)$ & $51,84( \pm 1,10)$ & $24,02( \pm 1,11)$ & $9,70( \pm 1,74)$ & $35,1( \pm 8,6)$ \\
\hline SP2 & 4 & $0,70( \pm 0,68)$ & $1,67( \pm 094)$ & $2,98( \pm 0,93)$ & $6,30( \pm 0,65)$ & $53,97( \pm 1,80)$ & $24,38( \pm 1,36)$ & $10,01( \pm 1,32)$ & $57,7( \pm 26,3)$ \\
\hline NG1 & 4 & $0,91( \pm 1,30)$ & $2,00( \pm 1,94)$ & $3,16( \pm 2,29)$ & $7,03( \pm 1,89)$ & $53,94( \pm 7,67)$ & $22,27( \pm 3,01)$ & $10,70( \pm 2,58)$ & $62,1( \pm 36,8)$ \\
\hline NG2 & 4 & $2,26( \pm 3,45)$ & $3,38( \pm 3,73)$ & $5,22( \pm 3,28)$ & $8,78( \pm 1,72)$ & $50,76( \pm 8,12)$ & $20,59( \pm 3,33)$ & $9,00( \pm 2,65)$ & $44,7( \pm 31,4)$ \\
\hline KS1 & 4 & $2,13( \pm 0,66)$ & $3,98( \pm 1,10)$ & $6,26( \pm 1,48)$ & $9,92( \pm 1,45)$ & $43,56( \pm 6,80)$ & $23,47( \pm 4,42)$ & $10,67( \pm 3,67)$ & $23,3( \pm 6,2)$ \\
\hline KS2 & 4 & $1,33( \pm 1,05)$ & $2,57( \pm 1,42)$ & $4,68( \pm 1,39)$ & $9,32( \pm 0,71)$ & $45,46( \pm 5,36)$ & $25,56( \pm 0,64)$ & $11,08( \pm 1,09)$ & $40,0( \pm 22,4)$ \\
\hline Average & & $1,16( \pm 1,42)$ & $2,27( \pm 1,79)$ & $3,81( \pm 2,03)$ & $8,47( \pm 1,88)$ & $53,43( \pm 8,47)$ & $21,67( \pm 4,03)$ & $9,20( \pm 2,78)$ & $47,8( \pm 25,5)$ \\
\hline $\min -\mathrm{ma}$ & & $0,02-7,40$ & $0,63-8,92$ & $1,46-9,87$ & $5,00-11,84$ & $34,62-66,83$ & $13,83-29,84$ & $3,50-14,35$ & $7,8-99,1$ \\
\hline \multicolumn{10}{|c|}{ Sand Sea } \\
\hline KS3 & 4 & $0,26( \pm 0,44)$ & $1,36( \pm 1,28)$ & $3,18( \pm 2,78)$ & $7,02( \pm 2,52)$ & $\underline{33,64( \pm 3,68)}$ & $\underline{52,10( \pm 4,44)}$ & $2,44( \pm 0,73)$ & $88,4( \pm 45,2)$ \\
\hline KS4 & 4 & $3,90( \pm 0,82)$ & $9,90( \pm 2,13)$ & $26,12( \pm 5,43)$ & $39,88( \pm 1,43)$ & $16,42( \pm 8,32)$ & $1,97( \pm 0,61)$ & $1,83( \pm 0,39)$ & $9,7( \pm 2,0)$ \\
\hline EG1 & 4 & $0,00( \pm 0,01)$ & $0,19( \pm 0,38)$ & $1,15( \pm 0,73)$ & $7,66( \pm 1,60)$ & $\underline{49,94( \pm 4,38)}$ & $35,48( \pm 3,72)$ & $5,58( \pm 1,19)$ & $117,0( \pm 21,8)$ \\
\hline EG2 & 4 & $0,16( \pm 0,19)$ & $0,67( \pm 0,61)$ & $2,21( \pm 0,73)$ & $11,00( \pm 3,22)$ & $\underline{53,98( \pm 3,79)}$ & $27,68( \pm 4,38)$ & $4,30( \pm 1,08)$ & $80,3( \pm 22,0)$ \\
\hline SS1 & 3 & $0,00( \pm 0,00)$ & $0,00( \pm 0,00)$ & $0,00( \pm 0,00)$ & $0,00( \pm 0,00)$ & $4,65( \pm 0,88)$ & $\underline{89,81( \pm 4,63)}$ & $5,55( \pm 5,49)$ & $249,2( \pm 170,9)$ \\
\hline SS2 & 4 & $0,00( \pm 0,00)$ & $0,00( \pm 0,00)$ & $0,00( \pm 0,00)$ & $0,13( \pm 0,27)$ & $2,79( \pm 3,18)$ & $\underline{88,32( \pm 4,71)}$ & $8,76( \pm 1,34)$ & $368,4( \pm 29,3)$ \\
\hline KK1 & 4 & $0,00( \pm 0,00)$ & $0,00( \pm 0,00)$ & $0,35( \pm 0,42)$ & $2,57( \pm 1,49)$ & $\underline{54,98( \pm 4,63)}$ & $37,60( \pm 5,45)$ & $4,50( \pm 1,19)$ & $204,9( \pm 117,7)$ \\
\hline KK2 & 4 & $0,00( \pm 0,00)$ & $0,00( \pm 0,00)$ & $0,77( \pm 0,24)$ & $5,22( \pm 2,23)$ & $\underline{53,90( \pm 5,82)}$ & $36,13( \pm 5,74)$ & $3,98( \pm 1,64)$ & $143,9( \pm 23,1)$ \\
\hline TS1 & 4 & $0,00( \pm 0,01)$ & $0,45( \pm 0,37)$ & $1,34( \pm 0,62)$ & $6,03( \pm 1,27)$ & $34,82( \pm 2,84)$ & $\underline{51,45( \pm 1,94)}$ & $5,91( \pm 0,56)$ & $116,3( \pm 16,3)$ \\
\hline TS2 & 4 & $0,00( \pm 0,00)$ & $0,00( \pm 0,00)$ & $0,23( \pm 0,21)$ & $1,70( \pm 1,37)$ & $\underline{36,25( \pm 7,03)}$ & $\underline{58,65( \pm 8,89)}$ & $3,16( \pm 2,32)$ & $192,2( \pm 30,9)$ \\
\hline TS3 & 4 & $0,00( \pm 0,00)$ & $0,00( \pm 0,00)$ & $0,84( \pm 0,18)$ & $6,62( \pm 1,19)$ & $\underline{48,73( \pm 5,27)}$ & $\underline{38,73( \pm 5,27)}$ & $5,08 \quad( \pm 1,39)$ & $140,4( \pm 17,8)$ \\
\hline Average & & $0,40( \pm 1,16)$ & $1,17( \pm 2,94)$ & $3,37( \pm 7,62)$ & $8,17( \pm 10,88)$ & $36,18( \pm 19,00)$ & $46,09( \pm 24,42)$ & $4,62( \pm 2,46)$ & $153,3( \pm 106,9)$ \\
\hline Min-ma & & $0,00-4,59$ & $0,00-11,84$ & $0,00-30,87$ & $0,00-41,52$ & $0,27-61,76$ & $1,24-92,90$ & $0,07-11,88$ & $8,2-399,5$ \\
\hline \multicolumn{10}{|c|}{ Kuiseb River } \\
\hline GB & 4 & $1,19( \pm 1,03)$ & $2,53( \pm 1,96)$ & $5,42( \pm 3,22)$ & $11,99( \pm 6,56)$ & $46,09( \pm 10,31)$ & $25,94( \pm 7,00)$ & $6,84( \pm 3,30)$ & $54,8( \pm 55,5)$ \\
\hline HM1 & 3 & $\underline{5,34( \pm 0,44)}$ & $\underline{10,39( \pm 0,97)}$ & $\underline{22,98( \pm 3,04)}$ & $\underline{36,52( \pm 2,08)}$ & $17,82( \pm 1,87)$ & $4,42( \pm 1,36)$ & $2,53( \pm 0,96)$ & $7,9( \pm 0,4)$ \\
\hline HM2 & 4 & $4,35( \pm 0,73)$ & $\underline{10,29( \pm 2,05)}$ & $\underline{28,59( \pm 6,09)}$ & $\underline{40,11( \pm 1,80)}$ & $13,69( \pm 8,23)$ & $1,64( \pm 0,76)$ & $1,33( \pm 0,44)$ & $9,0( \pm 1,6)$ \\
\hline Average & & $3,47( \pm 1,99)$ & $7,50( \pm 4,25)$ & $18,63( \pm 11,46)$ & $28,91( \pm 14,03)$ & $26,60( \pm 17,17)$ & $11,23( \pm 12,35)$ & $3,66( \pm 3,18)$ & $25,4( \pm 38,3)$ \\
\hline Min-ma & & $0,00-5,81$ & $0,00-12,55$ & $1,10-33,98$ & $3,47-42,72$ & $7,63-53,11$ & $0,82-33,38$ & $0,71-9,95$ & $7,5-137,0$ \\
\hline
\end{tabular}


Central Namib Desert

Table S1 (continued)

\begin{tabular}{|c|c|c|c|c|c|c|c|c|c|}
\hline $\begin{array}{l}\text { Sample } \\
\text { Name }\end{array}$ & $\#$ & $\begin{array}{c}P(\mathrm{mg} / \mathrm{kg}) \\
(\mathrm{P})\end{array}$ & $\begin{array}{c}\mathrm{S}(\mathrm{mg} / \mathrm{kg}) \\
(\mathrm{S})\end{array}$ & $\begin{array}{c}\mathrm{Ca}(\mathrm{mg} / \mathrm{kg}) \\
(\mathrm{Ca})\end{array}$ & $\begin{array}{c}\mathrm{K}(\mathrm{mg} / \mathrm{kg}) \\
(\mathrm{K})\end{array}$ & $\begin{array}{c}\mathrm{Mg}(\mathrm{mg} / \mathrm{kg}) \\
(\mathrm{Mg})\end{array}$ & $\begin{array}{c}\mathrm{Na}(\mathrm{mg} / \mathrm{kg}) \\
(\mathrm{Na})\end{array}$ & $\begin{array}{c}\mathrm{Cu}(\mathrm{mg} / \mathrm{kg}) \\
(\mathrm{Cu})\end{array}$ & $\begin{array}{c}\mathrm{Fe}(\mathrm{mg} / \mathrm{kg}) \\
(\mathrm{Fe})\end{array}$ \\
\hline \multicolumn{10}{|c|}{ Gravel Plains } \\
\hline QS1 & 4 & $16,08( \pm 2,86)$ & $0,8( \pm 1,6)$ & $2022( \pm 386)$ & $235( \pm 13)$ & $63,7( \pm 5,2)$ & $46( \pm 51)$ & $0,683( \pm 0,249)$ & $7,22( \pm 1,69)$ \\
\hline QS2 & 4 & $12,40( \pm 1,67)$ & $19,4( \pm 15,2)$ & $1755( \pm 518)$ & $367( \pm 184)$ & $62,4 \quad( \pm 7,1)$ & $134( \pm 170)$ & $0,138( \pm 0,015)$ & $8,42( \pm 2,35)$ \\
\hline SP1 & 4 & $6,68( \pm 1,10)$ & $\underline{3055,1}( \pm 1278,2)$ & $3126( \pm 1095)$ & $1495( \pm 192)$ & $107,1( \pm 33,8)$ & $36557( \pm 2351)$ & $0,169( \pm 0,052)$ & $7,04( \pm 2,40)$ \\
\hline SP2 & 4 & $6,18( \pm 2,69)$ & $\underline{3429,9( \pm 3281,5)}$ & $3533( \pm 2766)$ & $1152( \pm 449)$ & $137,6( \pm 25,0)$ & $\underline{36801( \pm 950)}$ & $0,032( \pm 0,038)$ & $9,10( \pm 1,90)$ \\
\hline NG1 & 4 & $9,39( \pm 2,37)$ & $47,3( \pm 61,4)$ & $1994( \pm 878)$ & $353( \pm 136)$ & $67,8( \pm 11,9)$ & $519( \pm 519)$ & $0,610( \pm 0,264)$ & $3,68( \pm 2,32)$ \\
\hline NG2 & 4 & $6,72( \pm 3,54)$ & $360,1( \pm 141,5)$ & $2983( \pm 852)$ & $503( \pm 103)$ & $188,8( \pm 89,8)$ & 1825 ( \pm 1499$)$ & $0,090( \pm 0,050)$ & $5,95( \pm 6,26)$ \\
\hline KS1 & 4 & $9,71( \pm 2,05)$ & $1664,2( \pm 2076,9)$ & $4990( \pm 1961)$ & $564( \pm 213)$ & $131,7( \pm 73,2)$ & $2811( \pm 2800)$ & $0,102( \pm 0,054)$ & $1,71( \pm 1,10)$ \\
\hline KS2 & 4 & $10,41( \pm 2,92)$ & $3199,8( \pm 5265,8)$ & $6662( \pm 5887)$ & $500( \pm 94)$ & $102,5( \pm 47,8)$ & 1561 ( \pm 1129$)$ & $0,099( \pm 0,046)$ & $4,39( \pm 4,36)$ \\
\hline \multicolumn{2}{|c|}{ Average ( \pm SD) } & $9,70( \pm 3,88)$ & $1472,1( \pm 2546,4)$ & $3383( \pm 2711)$ & $646( \pm 460)$ & $107,7( \pm 59,0)$ & $10032( \pm 15712)$ & $0,240( \pm 0,269)$ & $5,94( \pm 3,71)$ \\
\hline \multicolumn{2}{|c|}{ Min-max } & $1,66-20,36$ & $0,0-11097,3$ & $1318-15047$ & $219-1773$ & $53,5-292,8$ & $17-38609$ & $0,000-0,995$ & $0,43-14,21$ \\
\hline \multicolumn{10}{|c|}{ Sand Sea } \\
\hline KS3 & 4 & $12,17( \pm 6,59)$ & $40,2( \pm 36,5)$ & $1532( \pm 600)$ & $191( \pm 53)$ & $69,0( \pm 23,0)$ & $279( \pm 236)$ & $0,803( \pm 0,658)$ & $31,48( \pm 14,03)$ \\
\hline KS4 & 4 & $44,89( \pm 8,00)$ & $370,6( \pm 230,6)$ & $4736( \pm 200)$ & $424( \pm 72)$ & $348,0( \pm 116,9)$ & $1152( \pm 1372)$ & $\underline{6,416( \pm 1,085)}$ & $\underline{66,06( \pm 8,87)}$ \\
\hline EG1 & 4 & $5,06( \pm 0,24)$ & $32,8( \pm 55,4)$ & $1548( \pm 728)$ & $361( \pm 185)$ & $102,1( \pm 57,2)$ & $1148( \pm 2133)$ & $0,010( \pm 0,017)$ & $5,99( \pm 2,34)$ \\
\hline EG2 & 4 & $5,54( \pm 1,12)$ & $26,7( \pm 31,9)$ & $2397( \pm 1001)$ & $365( \pm 129)$ & $165,1( \pm 92,3)$ & $1052( \pm 1475)$ & $0,015( \pm 0,019)$ & $4,70( \pm 2,18)$ \\
\hline SS1 & 3 & $1,57( \pm 0,06)$ & $0,8( \pm 0,1)$ & $170( \pm 71)$ & $146( \pm 54)$ & $22,2( \pm 7,4)$ & $131( \pm 50)$ & $0,000( \pm 0,000)$ & $4,09( \pm 0,70)$ \\
\hline SS2 & 4 & $1,36( \pm 0,14)$ & $1,1( \pm 0,1)$ & $279( \pm 39)$ & $178( \pm 82)$ & $23,2( \pm 5,6)$ & $134( \pm 26)$ & $0,000( \pm 0,000)$ & $5,06( \pm 0,63)$ \\
\hline KK1 & 4 & $3,99( \pm 0,24)$ & $3,1( \pm 1,4)$ & $737( \pm 120)$ & $345( \pm 87)$ & $74,0 \quad( \pm 5,9)$ & $81( \pm 14)$ & $0,000( \pm 0,000)$ & $10,67( \pm 0,95)$ \\
\hline KK2 & 4 & $3,30( \pm 0,49)$ & $3,2( \pm 0,5)$ & $1291( \pm 886)$ & $304( \pm 23)$ & $83,5 \quad( \pm 8,8)$ & $138( \pm 75)$ & $0,001( \pm 0,001)$ & $9,29( \pm 4,08)$ \\
\hline TS1 & 4 & $3,09( \pm 0,57)$ & $323,1( \pm 243,4)$ & $2623( \pm 1790)$ & $354( \pm 75)$ & $123,2( \pm 67,3)$ & $1827( \pm 1565)$ & $0,000( \pm 0,000)$ & $7,25( \pm 1,85)$ \\
\hline TS2 & 4 & $3,07( \pm 0,41)$ & $228,2( \pm 252,5)$ & $1494( \pm 258)$ & $141( \pm 42)$ & $64,9( \pm 10,1)$ & $70( \pm 23)$ & $0,003( \pm 0,004)$ & $6,32( \pm 1,59)$ \\
\hline TS3 & 4 & $4,18( \pm 0,41)$ & $79,2( \pm 80,4)$ & $2047( \pm 1407)$ & $231( \pm 50)$ & $75,9( \pm 12,3)$ & $130( \pm 81)$ & $0,021( \pm 0,025)$ & $10,61( \pm 4,21)$ \\
\hline \multicolumn{2}{|c|}{ Average $( \pm S D)$} & $8,17( \pm 12,54)$ & $103,1( \pm 177,3)$ & $1750( \pm 1434)$ & $279( \pm 124)$ & $106,6( \pm 99,1)$ & $568( \pm 1074)$ & $0,676( \pm 1,905)$ & $14,93( \pm 18,79)$ \\
\hline \multicolumn{2}{|c|}{ Min-max } & $1,21-50,68$ & $0,0-591,8$ & $95-5263$ & $92-636$ & $14,6-493,8$ & $38-4347$ & $0,000-7,929$ & $2,68-70,65$ \\
\hline \multicolumn{10}{|c|}{ Kuiseb River } \\
\hline GB & 4 & $7,23( \pm 7,40)$ & $462,3( \pm 589,6)$ & $3341( \pm 1381)$ & $736( \pm 524)$ & $197,7( \pm 80,7)$ & $7915( \pm 10443)$ & $0,121( \pm 0,021)$ & $5,45( \pm 3,40)$ \\
\hline HM1 & 3 & $6,47( \pm 10,03)$ & $7958,7( \pm 5696,4)$ & $15636( \pm 7132)$ & $434( \pm 35)$ & $169,3( \pm 84,8)$ & $337( \pm 521)$ & $1,159( \pm 0,155)$ & $4,34( \pm 0,93)$ \\
\hline HM2 & 4 & $13,31( \pm 3,99)$ & $19,5( \pm 2,5)$ & $4526( \pm 280)$ & $436( \pm 54)$ & $190,4( \pm 15,7)$ & $418( \pm 210)$ & $0,691( \pm 0,110)$ & $6,551( \pm 1,22)$ \\
\hline \multicolumn{2}{|c|}{ Average ( \pm SD) } & $9,23( \pm 7,20)$ & $2345,8( \pm 4430,5)$ & $7125( \pm 6397)$ & $544( \pm 326)$ & $180,8( \pm 59,6)$ & $3122( \pm 6872)$ & $0,611( \pm 0,444)$ & $5,53( \pm 2,21)$ \\
\hline \multicolumn{2}{|c|}{ Min-max } & $0,40-18,05$ & $17,7-14353,3$ & $1430-23653$ & $230-1304$ & $63,2-263,6$ & $33-22452$ & $0,094-1,256$ & $2,08-9,11$ \\
\hline
\end{tabular}

\section{Central Namib Desert}


Table S1 (continued)

\begin{tabular}{|c|c|c|c|c|c|c|c|c|c|}
\hline $\begin{array}{l}\text { Sample } \\
\text { Name. }\end{array}$ & $\#$ & $\begin{array}{c}\mathrm{Mn}(\mathrm{mg} / \mathrm{kg}) \\
(\mathrm{Mn})\end{array}$ & $\begin{array}{l}\mathrm{Al}(\mathrm{mg} / \mathrm{kg}) \\
\text { (Al) }\end{array}$ & $\begin{array}{c}\mathrm{Cd}(\mathrm{mg} / \mathrm{kg}) \\
(\mathrm{Cd})\end{array}$ & $\begin{array}{c}\mathrm{Cr}(\mathrm{mg} / \mathrm{kg}) \\
(\mathrm{Cr})\end{array}$ & $\begin{array}{l}\mathrm{Ni}(\mathrm{mg} / \mathrm{kg}) \\
(\mathrm{Ni})\end{array}$ & $\begin{array}{c}\mathrm{Zn}(\mathrm{mg} / \mathrm{kg}) \\
(\mathrm{Zn})\end{array}$ & $\begin{array}{c}\mathrm{V}(\mathrm{mg} / \mathrm{kg}) \\
(\mathrm{V})\end{array}$ & $\begin{array}{c}\mathrm{Co}(\mathrm{mg} / \mathrm{kg}) \\
(\mathrm{Co})\end{array}$ \\
\hline \multicolumn{10}{|c|}{ Gravel Plains } \\
\hline QS1 & 4 & $8,56( \pm 2,22)$ & $\underline{45,86( \pm 13,85)}$ & $0,004( \pm 0,001)$ & $0,026( \pm 0,004)$ & $0,028( \pm 0,022)$ & $0,355( \pm 0,055)$ & $0,112( \pm 0,015)$ & $0,077( \pm 0,021)$ \\
\hline QS2 & 4 & $10,79( \pm 2,48)$ & $43,59( \pm 10,58)$ & $0,01( \pm 0,001)$ & $0,096( \pm 0,105)$ & $0,000( \pm 0,000)$ & $0,118( \pm 0,083)$ & $0,128( \pm 0,017)$ & $0,098( \pm 0,027)$ \\
\hline SP1 & 4 & $4,21( \pm 1,64)$ & $\overline{12,49( \pm 4,66)}$ & $0,008( \pm 0,001)$ & $0,000( \pm 0,000)$ & $0,000( \pm 0,000)$ & $0,000( \pm 0,000)$ & $0,440( \pm 0,313)$ & $0,040( \pm 0,013)$ \\
\hline SP2 & 4 & $6,13( \pm 0,78)$ & $16,34( \pm 2,62)$ & $0,006( \pm 0,002)$ & $0,022( \pm 0,034)$ & $0,001 \quad( \pm 0,001)$ & $0,000( \pm 0,000)$ & $0,399( \pm 0,324)$ & $0,054( \pm 0,003)$ \\
\hline NG1 & 4 & $4,01( \pm 1,56)$ & $17,02( \pm 10,40)$ & $0,004( \pm 0,002)$ & $0,006( \pm 0,009)$ & $0,000( \pm 0,000)$ & $0,218( \pm 0,027)$ & $0,091( \pm 0,030)$ & $0,029( \pm 0,015)$ \\
\hline NG2 & 4 & $4,25( \pm 3,42)$ & $16,04( \pm 14,46)$ & $0,012( \pm 0,003)$ & $0,105( \pm 0,157)$ & $0,000( \pm 0,000)$ & $0,001( \pm 0,002)$ & $0,167( \pm 0,167)$ & $0,039( \pm 0,029)$ \\
\hline KS1 & 4 & $2,91( \pm 1,13)$ & $4,85( \pm 0,98)$ & $0,012( \pm 0,001)$ & $0,051( \pm 0,102)$ & $0,000( \pm 0,000)$ & $0,002( \pm 0,003)$ & $0,033( \pm 0,024)$ & $0,026( \pm 0,006)$ \\
\hline KS2 & 4 & $5,25( \pm 3,61)$ & $16,19( \pm 15,41)$ & $0,012( \pm 0,002)$ & $0,068( \pm 0,116)$ & $0,000( \pm 0,000)$ & $0,014( \pm 0,028)$ & $0,143( \pm 0,129)$ & $0,048( \pm 0,030)$ \\
\hline Average & & $5,76( \pm 3,24)$ & $21,55( \pm 16,89)$ & $0,008( \pm 0,004)$ & $0,047( \pm 0,085)$ & $0,004( \pm 0,012)$ & $0,088( \pm 0,131)$ & $0,189( \pm 0,209)$ & $0,051( \pm 0,030)$ \\
\hline Min-max & & $0,96-13,87$ & $2,47-66,04$ & $0,002-0,015$ & $0,000-0,339$ & $0,000-0,053$ & $0,000-0,396$ & $0,000-0,901$ & $0,009-0,128$ \\
\hline \multicolumn{10}{|c|}{ Sand Sea } \\
\hline KS3 & 4 & $39,78( \pm 14,92)$ & $\underline{22,51( \pm 9,72)}$ & $0,011( \pm 0,008)$ & $0,201( \pm 0,312)$ & $0,073( \pm 0,075)$ & $0,104( \pm 0,093)$ & $0,596( \pm 0,412)$ & $0,291( \pm 0,097)$ \\
\hline KS4 & 4 & $83,39( \pm 8,14)$ & $\overline{17,13( \pm 6,29)}$ & $\underline{0,098( \pm 0,019)}$ & $\underline{0,199( \pm 0,227)}$ & $\underline{0,653( \pm 0,128)}$ & $1,199( \pm 0,077)$ & $\underline{0,665( \pm 0,251)}$ & $\underline{0,567( \pm 0,086)}$ \\
\hline EG1 & 4 & $2,58( \pm 0,91)$ & $\overline{24,92( \pm 9,98)}$ & $\overline{0,002( \pm 0,002)}$ & $\overline{0,030( \pm 0,012)}$ & $\overline{0,000( \pm 0,000)}$ & $\overline{0,013( \pm 0,027)}$ & $\overline{0,095( \pm 0,042)}$ & $\overline{0,036( \pm 0,013)}$ \\
\hline EG2 & 4 & $2,25( \pm 0,63)$ & $\overline{19,82( \pm 13,67)}$ & $0,004( \pm 0,002)$ & $0,020( \pm 0,012)$ & $0,000( \pm 0,000)$ & $0,012( \pm 0,024)$ & $0,155( \pm 0,081)$ & $0,031( \pm 0,010)$ \\
\hline SS1 & 3 & $0,40( \pm 0,26)$ & $\overline{11,09( \pm 1,89)}$ & $0( \pm 0)$ & $0,016( \pm 0,009)$ & $0,000( \pm 0,000)$ & $0,000( \pm 0,000)$ & $0,036( \pm 0,012)$ & $0,009( \pm 0,004)$ \\
\hline ss2 & 4 & $1,21( \pm 0,26)$ & $12,92( \pm 1,41)$ & $0,001( \pm 0,001)$ & $0,014( \pm 0,003)$ & $0,000( \pm 0,000)$ & $0,020( \pm 0,040)$ & $0,057( \pm 0,010)$ & $0,030( \pm 0,006)$ \\
\hline KK1 & 4 & $3,69( \pm 0,40)$ & $35,22( \pm 4,84)$ & $0,001( \pm 0,001)$ & $0,111( \pm 0,104)$ & $0,000( \pm 0,000)$ & $0,000( \pm 0,001)$ & $0,160( \pm 0,017)$ & $0,056( \pm 0,007)$ \\
\hline KK2 & 4 & $3,21( \pm 1,21)$ & $31,13( \pm 13,44)$ & $0,001( \pm 0,001)$ & $0,198( \pm 0,191)$ & $0,000( \pm 0,000)$ & $0,004( \pm 0,008)$ & $0,138( \pm 0,026)$ & $0,049( \pm 0,020)$ \\
\hline TS1 & 4 & $2,09( \pm 0,42)$ & $20,47( \pm 5,20)$ & $0,004( \pm 0,001)$ & $0,158( \pm 0,234)$ & $0,000( \pm 0,000)$ & $0,264( \pm 0,114)$ & $7,864( \pm 6,886)$ & $0,036( \pm 0,006)$ \\
\hline TS2 & 4 & $1,68( \pm 0,47)$ & $28,52( \pm 8,96)$ & $0( \pm 0)$ & $0,029( \pm 0,014)$ & $0,000( \pm 0,000)$ & $0,383( \pm 0,049)$ & $1,584( \pm 0,960)$ & $0,038( \pm 0,013)$ \\
\hline TS3 & 4 & $3,12( \pm 1,05)$ & $37,46( \pm 16,14)$ & $0,001( \pm 0)$ & $0,439( \pm 0,182)$ & $0,003( \pm 0,005)$ & $0,200( \pm 0,236)$ & $1,922( \pm 1,064)$ & $0,055( \pm 0,022)$ \\
\hline Average & & $13,33( \pm 25,64)$ & $24,04( \pm 11,77)$ & $0,011( \pm 0,029)$ & $0,131( \pm 0,190)$ & $0,068( \pm 0,195)$ & $0,205( \pm 0,355)$ & $1,234( \pm 2,925)$ & $0,111( \pm 0,169)$ \\
\hline Min-max & & $0,12-93,64$ & $8,97-50,07$ & $0,000-0,125$ & $0,005-0,668$ & $0,000-0,799$ & $0,000-1,278$ & $0,022-15,857$ & $0,007-0,663$ \\
\hline \multicolumn{10}{|c|}{ Kuiseb River } \\
\hline GB & 4 & $11,93( \pm 6,17)$ & $7,63( \pm 10,54)$ & $0,009( \pm 0,001)$ & $0,010( \pm 0,020)$ & $0,000( \pm 0,000)$ & $0,013( \pm 0,025)$ & $0,084( \pm 0,055)$ & $0,045( \pm 0,024)$ \\
\hline HM1 & 3 & $5,90( \pm 3,51)$ & $3,94( \pm 6,83)$ & $0,024( \pm 0,024)$ & $0,003( \pm 0,004)$ & $0,000( \pm 0,000)$ & $0,350( \pm 0,193)$ & $0,051( \pm 0,006)$ & $0,002( \pm 0,003)$ \\
\hline HM2 & 4 & $19,71( \pm 3,43)$ & $11,72( \pm 0,78)$ & $0,027( \pm 0,006)$ & $0,059( \pm 0,103)$ & $0,000( \pm 0,000)$ & $0,156( \pm 0,046)$ & $0,064( \pm 0,028)$ & $0,086( \pm 0,017)$ \\
\hline Average & & $13,12( \pm 7,14)$ & $8,11( \pm 7,31)$ & $0,020( \pm 0,014)$ & $0,026( \pm 0,064)$ & $0,000( \pm 0,000)$ & $0,157( \pm 0,167)$ & $0,068( \pm 0,037)$ & $0,048( \pm 0,039)$ \\
\hline Min-max & & $3,50-24,41$ & $0,00-23,29$ & $0,007-0,051$ & $0,000-0,214$ & $0,000-0,000$ & $0,000-0,462$ & $0,027-0,154$ & $0,000-0,109$ \\
\hline \multicolumn{10}{|c|}{ Central Namib Desert } \\
\hline Average & & $10,49( \pm 18,65)$ & $21,08( \pm 14,32)$ & $0,011( \pm 0,021)$ & $0,086( \pm 0,152)$ & $0,035( \pm 0,141)$ & $0,155( \pm 0,273)$ & $0,696( \pm 2,130)$ & $0,081( \pm 0,125)$ \\
\hline
\end{tabular}


Table S2: ADONIS analyses informing on differences in environmental characteristics and T-RFLP profiles between the three terrain types. The adjusted $p$ value of the Tukey test indicates towards differences in the homogeneity of group variances. Significant $p$ values $(p<0.05)$ are indicated with an asterisk.

\begin{tabular}{l|ccc}
\hline \multicolumn{1}{c|}{ Environments } & $\begin{array}{c}\text { ADONIS } \\
\mathbf{F}\end{array}$ & $\begin{array}{c}\text { ADONIS } \\
\mathbf{p}\end{array}$ & $\begin{array}{c}\text { Tukey } \\
\mathbf{p}\end{array}$ \\
\hline $\begin{array}{l}\text { Abiotic: Environmental data } \\
\text { Overall }\end{array}$ & 8.8608 & $0.001^{*}$ & \\
Pairwise & & & \\
$\quad$ Gravel Plains - Dunes & 15.344 & $0.001^{*}$ & $0.0002^{*}$ \\
$\quad$ Gravel Plains - River & 2.2892 & 0.128 & 0.4956 \\
$\quad$ Dunes - River & 15.17 & $0.001^{*}$ & 0.1989 \\
Biotic: T-RFLP data & & & \\
Overall & 3.5483 & $0.001^{*}$ & \\
Pairwise & & & \\
$\quad$ Gravel Plains - Dunes & 3.6304 & $0.001^{*}$ & 0.5805 \\
$\quad$ Gravel Plains - River & 2.1018 & $0.029^{*}$ & 0.9965 \\
$\quad$ Dunes - River & 4.6533 & $0.001^{*}$ & 0.8166 \\
\hline
\end{tabular}


Table S3: ADONIS analyses informing on differences in environmental characteristics and T-RFLP profiles between geologic units, with the adjusted $\mathrm{p}$ value of the Tukey test indicating towards differences in the homogeneity of group variances.

The salt, silt, dune and metal columns indicate if one of the compared pair belongs to a specific lithology (SP, HM, SS \& KS3\&4 respectively). Significant $p$ values $(p<0.05)$ are indicated with an asterisk.

\begin{tabular}{|c|c|c|c|c|c|c|c|c|c|c|}
\hline & \multirow[b]{2}{*}{$\frac{t}{\sqrt{n}}$} & \multirow[b]{2}{*}{$\frac{ \pm}{\bar{n}}$} & \multirow[b]{2}{*}{ 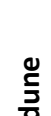 } & \multirow[b]{2}{*}{$\stackrel{\bar{\pi}}{\stackrel{d}{\varepsilon}}$} & \multicolumn{3}{|c|}{ Environmental variables } & \multicolumn{3}{|c|}{ T-RFLP data } \\
\hline & & & & & $\begin{array}{c}\text { ADONIS } \\
F\end{array}$ & $\begin{array}{c}\text { ADONIS } \\
p\end{array}$ & $\begin{array}{c}\text { Tukey } \\
\text { p }\end{array}$ & $\begin{array}{c}\text { ADONIS } \\
F\end{array}$ & $\begin{array}{c}\text { ADONIS } \\
p\end{array}$ & $\begin{array}{c}\text { Tukey } \\
\text { p }\end{array}$ \\
\hline Overall & & & & & 59.027 & $0.001^{*}$ & & 4.2953 & $0.001^{*}$ & \\
\hline $\mathrm{SP}-\mathrm{HM}$ & $x$ & $x$ & & & 114.86 & $0.001^{*}$ & 0.6999 & 2.9162 & $0.009 *$ & 1.0000 \\
\hline$S P-S S$ & $x$ & & $x$ & & 775.9 & $0.001 *$ & 0.9291 & 5.3329 & $0.001 *$ & 0.9871 \\
\hline$S P-K S 3 \& 4$ & $x$ & & & $x$ & 635.44 & $0.001 *$ & 0.9999 & 5.1254 & $0.001 *$ & 0.9989 \\
\hline$S P-K S 1 \& 2$ & $x$ & & & & 198.68 & $0.001^{*}$ & 0.9989 & 2.2733 & 0.039* & 0.7118 \\
\hline$S P-E G$ & $x$ & & & & 643.68 & $0.001 *$ & 0.9999 & 7.4251 & $0.001^{*}$ & 0.9416 \\
\hline$S P-G B$ & $x$ & & & & 53.08 & $0.008^{*}$ & 0.3094 & 3.2996 & $0.01 *$ & 0.9569 \\
\hline$S P-K K$ & $x$ & & & & 862.92 & $0.001^{*}$ & 0.9655 & 8.7723 & $0.001^{*}$ & 0.9637 \\
\hline$S P-Q S$ & $x$ & & & & 875.85 & $0.002 *$ & 0.9626 & 8.4162 & $0.001 *$ & 0.9964 \\
\hline $\mathrm{SP}-\mathrm{TS}$ & $x$ & & & & 948.87 & $0.001^{*}$ & 0.9966 & 7.3715 & $0.001^{*}$ & 0.9999 \\
\hline$S P-N G$ & $\mathrm{x}$ & & & & 693.33 & $0.001 *$ & 0.9996 & 6.173 & $0.001 *$ & 1.0000 \\
\hline HM - SS & & $x$ & $x$ & & 8.1017 & $0.003^{*}$ & 0.0568 & 5.2066 & $0.002^{*}$ & 0.9877 \\
\hline $\mathrm{HM}-\mathrm{KS} 3 \& 4$ & & $x$ & & $x$ & 4.5378 & $0.012^{*}$ & 0.3843 & 5.2994 & $0.001^{*}$ & 0.9989 \\
\hline $\mathrm{HM}-\mathrm{KS} 1 \& 2$ & & $x$ & & & 1.0649 & 0.357 & 0.9882 & 2.8604 & $0.007^{*}$ & 0.7338 \\
\hline$H M-G B$ & & $x$ & & & 2.8132 & $0.024 *$ & 0.9984 & 3.0981 & $0.001 *$ & 0.9583 \\
\hline$H M-E G$ & & $\mathrm{x}$ & & & 6.1932 & $0.001^{*}$ & 0.3072 & 10.229 & $0.001 *$ & 0.9596 \\
\hline $\mathrm{HM}-\mathrm{KK}$ & & $x$ & & & 7.9455 & $0.001 *$ & 0.0719 & 9.7999 & $0.001 *$ & 0.9757 \\
\hline $\mathrm{HM}-\mathrm{QS}$ & & $x$ & & & 6.6073 & $0.001 *$ & 0.0691 & 6.8839 & $0.001 *$ & 0.9979 \\
\hline $\mathrm{HM}-\mathrm{TS}$ & & $x$ & & & 9.0486 & $0.001 *$ & 0.1099 & 6.8259 & $0.001 *$ & 0.9999 \\
\hline$H M-N G$ & & $\mathrm{x}$ & & & 5.4976 & $0.001 *$ & 0.2488 & 6.6525 & $0.002 *$ & 1.0000 \\
\hline SS - KS3\&4 & & & $x$ & $x$ & 14.458 & $0.001 *$ & 0.9957 & 2.7084 & $0.006^{*}$ & 0.9999 \\
\hline$S S$ - EG & & & $x$ & & 7.4815 & $0.003 *$ & 0.9987 & 4.537 & $0.002^{*}$ & 0.3219 \\
\hline $\mathrm{SS}-\mathrm{KK}$ & & & $x$ & & 10.693 & $0.001 *$ & 1.0000 & 5.8528 & $0.001^{*}$ & 0.3785 \\
\hline SS - QS & & & $x$ & & 80.55 & $0.001 *$ & 1.0000 & 4.4911 & $0.001 *$ & 0.6040 \\
\hline$S S$ - NG & & & $x$ & & 17.279 & $0.001 *$ & 0.9996 & 3.1323 & $0.003 *$ & 0.9519 \\
\hline SS - TS & & & $x$ & & 8.1247 & $0.003 *$ & 0.9998 & 1.7219 & 0.088 & 0.9993 \\
\hline SS - KS1\&2 & & & $x$ & & 8.0034 & $0.001 *$ & 0.4722 & 2.3551 & $0.007^{*}$ & 0.9997 \\
\hline$S S-G B$ & & & $\mathrm{x}$ & & 4.8494 & $0.005^{*}$ & $0.0185^{*}$ & 1.0557 & 0.454 & 0.9999 \\
\hline KS3\&4 - EG & & & & $x$ & 1.5441 & 0.264 & 1.0000 & 2.6369 & $0.032 *$ & 0.4813 \\
\hline KS3\&4 - KK & & & & $x$ & 8.3731 & $0.014 *$ & 0.9991 & 5.7659 & $0.001 *$ & 0.5489 \\
\hline KS3\&4 - QS & & & & $x$ & 3.5805 & 0.053 & 0.9989 & 5.7041 & $0.001 *$ & 0.7776 \\
\hline KS3\&4 - NG & & & & $\mathrm{x}$ & 0.77562 & 0.498 & 1.0000 & 1.9058 & 0.096 & 0.9914 \\
\hline KS3\&4 - KS1\&2 & & & & $\mathrm{x}$ & 2.8598 & 0.064 & 0.9628 & 1.9619 & $0.039 *$ & 0.9916 \\
\hline KS3\&4 - GB & & & & $x$ & 3.8087 & 0.07 & 0.1369 & 1.718 & 0.091 & 0.9998 \\
\hline KS3\&4 - TS & & & & $x$ & 1.6342 & 0.203 & 0.9999 & 4.2987 & $0.001 *$ & 0.9999 \\
\hline $\mathrm{KS} 1 \& 2-\mathrm{EG}$ & & & & & 4.3808 & $0.003 *$ & 0.9302 & 3.2102 & $0.001 *$ & 0.0504 \\
\hline KS1\&2 - KK & & & & & 7.321 & $0.002 *$ & 0.5578 & 4.1157 & $0.003 *$ & 0.0655 \\
\hline KS1\&2 - QS & & & & & 5.6873 & $0.001 *$ & 0.5469 & 2.9359 & $0.002 *$ & 0.1530 \\
\hline$G B-E G$ & & & & & 3.5913 & 0.071 & 0.1055 & 2.3505 & $0.02 *$ & 0.3215 \\
\hline $\mathrm{GB}-\mathrm{KK}$ & & & & & 5.2678 & $0.008^{*}$ & $0.0235^{*}$ & 2.9309 & $0.003 *$ & 0.3690 \\
\hline NG - KS1\&2 & & & & & 3.5488 & $0.011^{*}$ & 0.8898 & 2.2381 & $0.027^{*}$ & 0.5476 \\
\hline $\mathrm{GB}-\mathrm{QS}$ & & & & & 5.0524 & $0.015^{*}$ & $0.0227^{*}$ & 1.8669 & $0.036^{*}$ & 0.5573 \\
\hline EG - TS & & & & & 0.33959 & 0.726 & 1.0000 & 6.4413 & $0.001^{*}$ & 0.6418 \\
\hline KK - TS & & & & & 3.3628 & $0.036 *$ & 0.9999 & 6.7863 & $0.001 *$ & 0.7132 \\
\hline $\mathrm{KS} 1 \& 2$ - TS & & & & & 6.4863 & $0.002^{*}$ & 0.7359 & 2.4533 & $0.008^{*}$ & 0.8676 \\
\hline$N G-G B$ & & & & & 3.5051 & 0.078 & 0.0834 & 1.4156 & 0.2 & 0.8992 \\
\hline QS - TS & & & & & 1.019 & 0.415 & 0.9999 & 5.7132 & $0.001 *$ & 0.9081 \\
\hline$E G-N G$ & & & & & 0.38937 & 0.665 & 1.0000 & 1.5486 & 0.162 & 0.9893 \\
\hline$N G-K K$ & & & & & 9.0016 & $0.001 *$ & 0.9999 & 5.5422 & $0.001^{*}$ & 0.9917 \\
\hline $\mathrm{GB}-\mathrm{TS}$ & & & & & 6.1887 & $0.024 *$ & $0.0368 *$ & 1.7159 & 0.08 & 0.9923 \\
\hline NG - TS & & & & & 0.79742 & 0.462 & 1.0000 & 4.7023 & $0.001^{*}$ & 0.9996 \\
\hline NG - QS & & & & & 4.5607 & $0.011^{*}$ & 0.9999 & 4.7533 & $0.002 *$ & 0.9997 \\
\hline$E G-Q S$ & & & & & 2.068 & 0.16 & 0.9998 & 7.8359 & $0.001^{*}$ & 0.9999 \\
\hline QS - KK & & & & & 9.1815 & $0.012 *$ & 1.0000 & 3.8264 & $0.001 *$ & 0.9999 \\
\hline$E G-K K$ & & & & & 3.6196 & $0.019 *$ & 0.9999 & 6.4957 & $0.001^{*}$ & 1.0000 \\
\hline $\mathrm{KS} 1 \& 2-\mathrm{GB}$ & & & & & 1.9482 & 0.079 & 0.7506 & 0.89409 & 0.574 & 1.0000 \\
\hline
\end{tabular}

